\title{
Programmable Universal Filter and Quadrature Oscillator Using Single Output Operational Transconductance Amplifiers
}

\author{
Boonying Knobnob ${ }^{1}$, Usa Torteanchai ${ }^{2}$, Montree Kumngern ${ }^{3}$
}

${ }^{1}$ Faculty of Engineering, Rajamangala University of Technology Thanyaburi, Pathum Thani, Thailand

${ }^{2}$ Aeronautical Engineering Division, Civil Aviation Training Center, Bangkok, Thailand ${ }^{3}$ Department of Telecommunications Engineering, School of Engineering, King Mongkut's Institute of Technology Ladkrabang, Bangkok, Thailand

\begin{abstract}
This paper presents a new programmable universal filter and quadrature oscillator based on the single output operational transconductance amplifiers (OTAs). The proposed universal filter and quadrature oscillator can be achieved into single topology by programming analog switches. When the circuit performs as a universal filter, it can realize low-pass, high-pass, band-pass, band-stop and all-pass filters with orthogonal and electronic controls of the natural frequency and quality factor. When the circuit performs as a quadrature oscillator, it provides a three-phase quadrature output signal which the condition and frequency of oscillations can be controlled orthogonally and electronically. The proposed structure can be realized based on the single output OTAs which are easily implemented as both commercially available integrated circuits (ICS) as OTAs and complementary metal-oxide semiconductor (CMOS) OTAs as IC forms. SPICE simulation using standard $0.18 \mu \mathrm{m}$ CMOS process is used for investigating the performance of the proposed circuit whereas the workability of new circuit is confirmed by LM13600 discrete-component integrated circuits as OTAs.
\end{abstract}

Keywords: Universal filter; quadrature oscillator; operational transconductance amplifier; analog signal processing; voltage-mode circuit

\section{Programirljiv univerzalni filter in kvadraturni oscilator z uporabo enojnih izhodnih operacijskih transkonduktančnih ojačevalnikov}

\begin{abstract}
Izvleček: Članek predstavlja nov programirljiv univerzalni filter in kvadraturni oscilator, ki temelji na enojnih izhodnih operacijskih transkonduktančnih ojačevalnikih (OTA). Predlagani univerzalni filter in kvadraturni oscilator je mogoče s programiranjem analognih stikal združiti v enotno topologijo. Ko vezje deluje kot univerzalni filter, lahko izvede nizkoprepustne, visokoprepustne, pasovne, zaporne in vseprepustne filtre z ortogonalnim in elektronskim upravljanjem lastne frekvence in faktorja kakovosti. Če vezje deluje kot kvadraturni oscilator, zagotavlja trifazni kvadraturni izhodni signal, katerega stanje in frekvenco oscilacij je mogoče ortogonalno in elektronsko krmiliti. Predlagano strukturo je mogoče realizirati na podlagi enojnih izhodnih OTA, ki jih je mogoče enostavno izvesti tako v obliki komercialno dostopnih integriranih vezij (IC) kot OTA kot komplementarnih kovinsko oksidnih polprevodniških (CMOS) OTA v obliki IC. Simulacija SPICE z uporabo standardnega 0,18 um CMOS procesa je uporabljena za raziskovanje delovanja predlaganega vezja, medtem ko je uporabnost novega vezja potrjena z diskretnimi integriranimi vezji LM13600 kot OTA.
\end{abstract}

Ključne besede: Univerzalni filter; kvadraturni oscilator; operacijski transkonduktančni ojačevalnik; analogna obdelava signalov; napetostno vezje

*Corresponding Author's e-mail: montree.ku@kmitl.com

How to cite:

B. Knobnob et al., "Programmable universal filter and quadrature oscillator using single output operational transconductance amplifiers", Inf. Midem-J. Microelectron. Electron. Compon. Mater., Vol. 51, No. 4(2021), pp. 225-241 


\section{Introduction}

The operational transconductance amplifiers (OTAs) are commonly used to realize analog signal processing circuits [1], [2]. There are numerous advantages of using OTA such as electronic tuning capability, simple structure, easy for implementing both bipolar junction transistor (BJT) and complementary metal oxide semiconductor (CMOS) with the same structure and powerful ability to generate various circuits. The OTA based circuits require no resistors therefore making it suitable for integrated circuits (ICs) implementation. There are discrete-component ICs as OTAs such as CA3080, LM13600, LM13700, NE5517 and MAX435 commercially available. It should be noted that discrete-component ICs as OTAs are single output devices therefore the utilization of single output OTA based circuits is very crucial. Although numerous outputs can be obtained by connecting the input terminals in paralled using discrete component ICs, the number of devices utilized will equal the number of required outputs, incresing the component count and power consumption.

The universal biquad filters are the topologies that usually provide variant second-order filtering responses from the same topology including low-pass (LP), bandpass (BP), high-pass (HP), band-stop (BS) and all-pass (AP). This filter can be applied to electronic, control and communication systems such as cross-over network used in a three-way high-fidelity loudspeaker, touchtone telephone used for tone decoders and phaselocked loop used for FM stereo demodulators [3]. Additionally, it can also be used as a subcircuit for realizing high-order filters [4]. Many universal biquad filters have been reported, for example, see [5]-[28]. OTAbased universal filters have been proposed already in [9]-[28]. Considering input and output terminals, these universal filters can be classified into three categories: (i) single-input multiple-output (SIMO) filter [9], [10], (ii) multiple-input single-output (MISO) filter [11]-[22] and (iii) multiple-input multiple-output (MIMO) filter [23][28]. The SIMO filter provides variant filtering responses for the output terminals of $L P, B P, H P, B S$, and AP when a single input signal is applied. The MISO filter delivers variant filtering responses by appropriately applying the input signal and output signal can be obtained with single output terminal while MIMO filter provides filtering responses by appropriately applying the input signals and appropriately selecting the output terminals. Compared to the SIMO filter, the MISO and MIMO filters usually require lesser active and passive elements. The voltage-mode universal filters typically require the properties such as high-input and low-output impedances to obviate additional buffer circuits, absent from inverting-type input signal requirements to avoid ad- ditional inverting amplifiers and orthogonal controls of the natural frequency and quality factor.

Quadrature oscillators are the circuits that usually provide two sinusoids with $90^{\circ}$ phase difference for a variety of applications such as for telecommunications in quadrature mixers, single-sideband generators, directconversion receivers or for measurement purposes in vector-generators and phase sensitive detection [29], [30]. Several quadrature oscillators have been reported, for example, see [30]-[36]. Quadrature oscillators that enjoy orthogonal control of the condition and frequency of oscillations are required. OTA-based quadrature oscillators have been proposed, for example, see [37]-[39].

Recently, the structures that can give both universal filter and quadrature oscillator have been reported [40]-[57]. The universal filter and quadrature oscillator can be obtained with the same topology [40]-[49] however, it is necessary to change the connection for obtaining either a universal filter or a quadrature oscillator. Futhermore, several of these topologies suffer from some drawbacks such as exciting the input signal through capacitors [40], [41], requiring componentmatching condition for obtaining all-pass filtering responses [42], [45], [47], [48], requiring minus-type input signal or double input signal for obtaining some filtering responses [43], lacking orthogonal control of the natural frequency and the quality factor [44] and obtaining the current output that flowing through capacitor which is not ideal for integrated circuits implementation [49].

The structure in [50] realizes universal filter and quadrature oscillator without changing any connection, but only LP, HP and BP filters are provided. The structure in [51] realizes quadrature oscillator and its structure can be modified to work as universal filter, but only LP and BP filtering responses are obtained. The structures in [52]-[57] realize universal filter and quadrature oscillator without changing any connection. In [52]-[53], either a universal filter or a quadrature oscillator can be obtained by selecting the switches, but passivematching condition is required for obtaining HP filtering response. In [54], the universal filter or the quadrature oscillator can be obtained by adjusting the ratio of resistances while in [55]-[57], the universal filter or the quadrature oscillator can be obtained by adjusting the ratio of bias currents. It is well-known that the filters are commonly realized based on linear system whereas oscillators are generally realized based on non-linear system. As a result, the condition for obtaining universal filter and quadrature oscillator by adjusting the ratio of resistances [54] and the ratio of bias currents [55][57] must be careful. Especially, in case of the circuits 
are operated as high-Q filters, self-oscillation must be avoided.

OTA-based universal filter and quadrature have been already reported [18], [25]-[28], but these systems provide universal filter and quadrature oscillator by adding or modifying the feedback connection.

This work proposes a new programmable voltagemode universal filter and three-phase quadrature oscillator using single output OTAs and grounded capacitors. Universal filter and quadrature oscillator can be achieved into single topology by programming using analog switches. If the circuit acts as universal filter, it is a four-input one-output universal filter that offers the advantages such as realizing $L P, B P, H P, B S$, and AP filters by appropriately applying input signal, without inverting-type signal requirements and high-input impedance. The natural frequency and quality factor can also be controlled orthogonally and electronically. In case the circuit works as quadrature oscillator, it is a threephase quadrature oscillator that the condition and frequency of oscillation can be controlled orthogonally and electronically. For IC implementation, the usage of grounded capacitor is ideal and the use of single-output OTAs is also easily implemented as commercially integrated circuits (ICs). SPICE simulation results using standard $0.18 \mu \mathrm{m}$ CMOS technology are used to verify the characteristic of the proposed circuit. The results of an experiment are used to confirm the workability of the new topology.
The comparison of the proposed circuit with those of previous universal filters and quadrature oscillators is shown in Table 1. Compared with the circuits in [53][54], the proposed circuit offers electronic controls, without component-matching condition, high input impedance and using ground capacitor. Compared with the current-mode circuits in [55]-[57], the proposed circuit offers a new technique for obtaining universal filter and quadrature oscillator. Namely the programmable technique which can be easy obtained universal filter or quadrature oscillator. If focusing only universal filter, the comparison of the proposed circuit with some universal filters is shown in Table 2. Comparing with voltage-mode universal filters in [20], [21], the proposed filter does not require component-matching condition or inverting-type input signal for obtaining five filtering responses. Compared with the currentmode universal filters in [46], [47], the proposed filter is absent from passive resistors.

\section{Proposed circuit}

The circuit symbol of OTA is shown in Fig. 1 and its ideal characteristic can be described by

$I_{o}=g_{m}\left(V_{i n+}-V_{i n-}\right)$

where $\mathrm{I}_{\mathrm{o}}$ is the output current, $\mathrm{g}_{\mathrm{m}}$ is the transconductance gain, $V_{\text {in }+}$ and $V_{\text {in- }}$ denote respectively non-inverting and inverting input terminals.

Table 1: Comparison of this work with those of previous universal filter and quadrature oscillator.

\begin{tabular}{|l|c|c|c|c|c|c|}
\hline Factor & {$[53]$} & {$[54]$} & {$[55]$} & {$[56]$} & {$[57]$} & Fig. 4 \\
\hline Number of active devices & 2-DVCC & 2-CFA & 3-CFTA & 2-CCCII & 2-CCFTA & 5-OTA \\
\hline Number passive components & 2-C, 2R & 2-C, 3-R & 2-C, 1-R & 2-C & 2-C & 2-C \\
\hline Operation mode & CM & VM & CM & CM & CM & VM \\
\hline Using grounded capacitor & Yes & No & Yes & Yes & Yes & Yes \\
\hline $\begin{array}{l}\text { Offer universal filter/quadrature oscillator } \\
\text { into single topology }\end{array}$ & Yes & Yes & Yes & Yes & Yes & Yes \\
\hline Technique to obtaining filter/oscillator & SW & Con & Con & Con & Con & Pro \\
\hline Independent control of $\omega_{\text {o }}$ and Q of filter & Yes & No & Yes & Yes & Yes & Yes \\
\hline $\begin{array}{l}\text { No component-matching condition for } \\
\text { obtaining five responses }\end{array}$ & No & No & Yes & Yes & Yes & Yes \\
\hline $\begin{array}{l}\text { Independent control of CO and FO of oscil- } \\
\text { lator }\end{array}$ & Yes & No & Yes & Yes & Yes & Yes \\
\hline Offer electronic controls & Yes & No & Yes & Yes & Yes & Yes \\
\hline Obtaining results & Sim/Exp & Sim & Sim & Sim/Exp & Sim & Sim/Exp \\
\hline
\end{tabular}

Note: CFA = current feedback amplifier, CFTA = current follower transconductance amplifier, CCCII = current controlled second-generation current conveyor, CCFTA = current controlled current follower transconductance amplifier, $\mathrm{VM}=$ voltage-mode, $\mathrm{CM}=$ current-mode, $\mathrm{SW}=$ using switch, $\mathrm{Con}=$ using condition, Pro = using programmable, Sim $=$ simulation, $\operatorname{Exp}=$ experimental 
Table 2: Comparison of this work with those of previous universal filters.

\begin{tabular}{|l|c|c|c|c|c|c|}
\hline Factor & {$[20]$} & {$[21]$} & {$[26]$} & {$[47]$} & {$[49]$} & Fig. 2 \\
\hline Number of active devices & 5-OTA & 5-OTA & 5-OTA & 2-VDCC & 1-VDGA & 5-OTA \\
\hline Number passive component & 2-C & 2-C & 2-C & 2-C \& 2-R & 2-C \& 2-R & 2-C \\
\hline Type of filter & MISO & MISO & MISO & SIMO & SIMO & MISO \\
\hline Independent control of $\omega_{\text {o }}$ and Q of filter & Yes & No & Yes & Yes & Yes & Yes \\
\hline $\begin{array}{l}\text { No component-matching condition for } \\
\text { obtaining five responses }\end{array}$ & No & No & Yes & No & No & Yes \\
\hline $\begin{array}{l}\text { No need of input inverting/matching for } \\
\text { Obtaining five filtering responses }\end{array}$ & Yes & No & Yes & Yes & Yes & Yes \\
\hline Offer electronic controls & Yes & Yes & Yes & Yes & Yes & Yes \\
\hline Obtaining results & Sim & Sim & Sim/Exp & Sim & Sim & Sim/Exp \\
\hline
\end{tabular}

Note: DVGA = voltage differencing gain amplifier, VDCC = voltage differencing current conveyor.

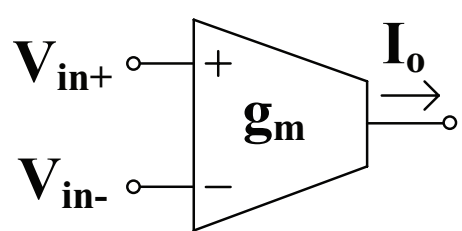

Figure 1: Electrical symbol of OTA.

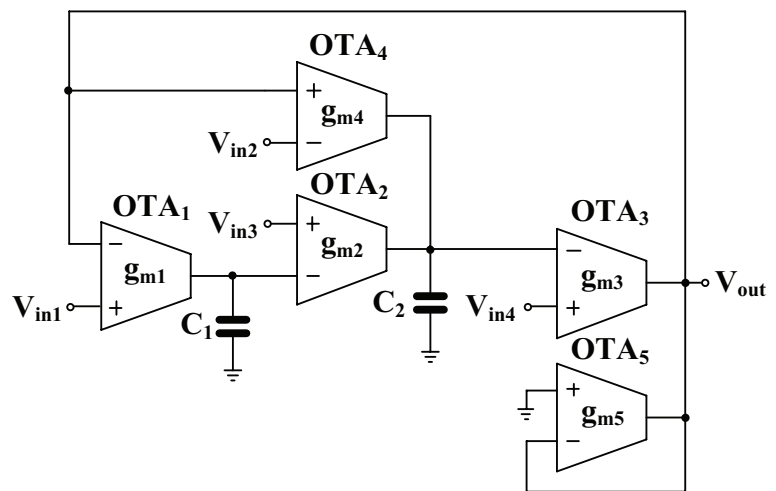

Figure 2: Universal biquad filter using single output OTAs.

Fig. 2 shows the voltage-mode universal biquad filter with four-input single-output using single output OTAs. This work is continuously developed next from previous work in [14]. The input signals $\mathrm{V}_{\text {in } 1}, \mathrm{~V}_{\text {in } 2}, \mathrm{~V}_{\text {in } 3}$ and $\mathrm{V}_{\text {in } 4}$ of filter are supplied to high impedance terminals of OTAs (infinite for ideal case), thus it requires no buffer circuits because the loading effect is vanished.

If $\mathrm{V}_{\text {in } 1^{\prime}} \mathrm{V}_{\text {in }{ }^{\prime}}, \mathrm{V}_{\text {in } 3}$ and $\mathrm{V}_{\text {in } 4}$ are input signal voltages, the output voltage of the proposed filter can be expressed by

$V_{\text {out }}=\frac{s^{2} C_{1} C_{2}\left(\frac{g_{m 3}}{g_{m 5}}\right) V_{i n 4}-s\left(\frac{C_{1} g_{m 2} g_{m 3}}{g_{m 5}}\right) V_{i n 3}+s\left(\frac{C_{1} g_{m 3} g_{m 4}}{g_{m 5}}\right) V_{i n 2}+\left(\frac{g_{m 1} g_{m 2} g_{m 3}}{g_{m 5}}\right) V_{i n 1}}{s^{2} C_{1} C_{2}+s\left(\frac{C_{1} g_{m 3} g_{m 4}}{g_{m 5}}\right)+\left(\frac{g_{m 1} g_{m 2} g_{m 3}}{g_{m 5}}\right)}$
From (2), five standard filtering responses can be obtained as

The non-inverting LP response: $V_{\mathrm{in} 2}=\mathrm{V}_{\mathrm{in} 3}=\mathrm{V}_{\mathrm{in} 4}=0$ (grounded), $\mathrm{V}_{\text {in } 1}=\mathrm{V}_{\text {in }}$.

The non-inverting BP response: $V_{i n 1}=V_{i n 3}=V_{i n 4}=0$ (grounded), $\mathrm{V}_{\text {in } 2}=\mathrm{V}_{\text {in }}$.

The inverting BP response: $\mathrm{V}_{\mathrm{in} 1}=\mathrm{V}_{\mathrm{in} 2}=\mathrm{V}_{\mathrm{in} 4}=0$ (grounded), $\mathrm{V}_{\text {in } 3}=\mathrm{V}_{\text {in }}$.

The non-inverting HP response: $\mathrm{V}_{\mathrm{in} 1}=\mathrm{V}_{\mathrm{in} 2}=\mathrm{V}_{\mathrm{in} 3}=0$ (grounded), $V_{\text {in } 4}=V_{\text {in }}$.

The non-inverting BS response: $V_{\text {in2 }}=V_{\text {in } 3}=0$ (grounded), $\mathrm{V}_{\text {in } 1}=\mathrm{V}_{\text {in } 4}=\mathrm{V}_{\text {in }}$.

The non-inverting AP response: $V_{\text {in2 }}=0$ (grounded), $\mathrm{V}_{\mathrm{in} 1}=\mathrm{V}_{\mathrm{in} 3}=\mathrm{V}_{\mathrm{in} 4}=\mathrm{V}_{\mathrm{in}}$.

Therefore, five standard filtering responses can be obtained by appropriately applying the input signals and realization to obtain these filtering functions without component-matching conditions and inverting-type input signal requirements. The output impedance of the proposed universal filter in Fig. 2 is given by $1 / g_{m 5}$.

The natural frequency $\left(\omega_{\mathrm{o}}\right)$ and quality factor $(\mathrm{Q})$ of all filtering responses can be expressed by

$$
\begin{aligned}
& \omega_{o}=\sqrt{\frac{g_{m 1} g_{m 3}}{C_{1} C_{2}} \cdot \frac{g_{m 2}}{g_{m 5}}} \\
& Q=\frac{1}{g_{m 4}} \sqrt{\frac{C_{2} g_{m 1}}{C_{1} g_{m 3}}\left(g_{m 2} g_{m 5}\right)}
\end{aligned}
$$

Letting $g_{m 2}=g_{m 5}=g_{m^{\prime}}$ (3) and (4) can be rewritten as

$\omega_{o}=\sqrt{\frac{g_{m 1} g_{m 3}}{C_{1} C_{2}}}$ 


$$
Q=\frac{g_{m}}{g_{m 4}} \sqrt{\frac{C_{2} g_{m 1}}{C_{1} g_{m 3}}}
$$

From (3) and (6), parameter $\omega_{\text {f }}$ for all filtering responses can be controlled electronically through $\mathrm{g}_{\mathrm{m} 1}$ and $\mathrm{g}_{\mathrm{m} 3}$ by keeping $\mathrm{g}_{\mathrm{m} 2}=\mathrm{g}_{\mathrm{m} 5}$ and $\mathrm{C}_{1}=\mathrm{C}_{2}$ while parameter $\mathrm{Q}$ can be controlled electronically and independently through $\mathrm{g}_{\mathrm{m}}\left(\mathrm{g}_{\mathrm{m}}=\mathrm{g}_{\mathrm{m} 2}=\mathrm{g}_{\mathrm{m} 5}\right)$ or $\mathrm{g}_{\mathrm{m} 4}$ by keeping $\mathrm{g}_{\mathrm{m} 1}=\mathrm{g}_{\mathrm{m} 3}$ and $\mathrm{C}_{1}=$ $\mathrm{C}_{2}$. This keeping is used only for easy to control parameters $\omega_{\mathrm{o}}$ and $\mathrm{Q}$ which is not meaning of componentmatching conditions.

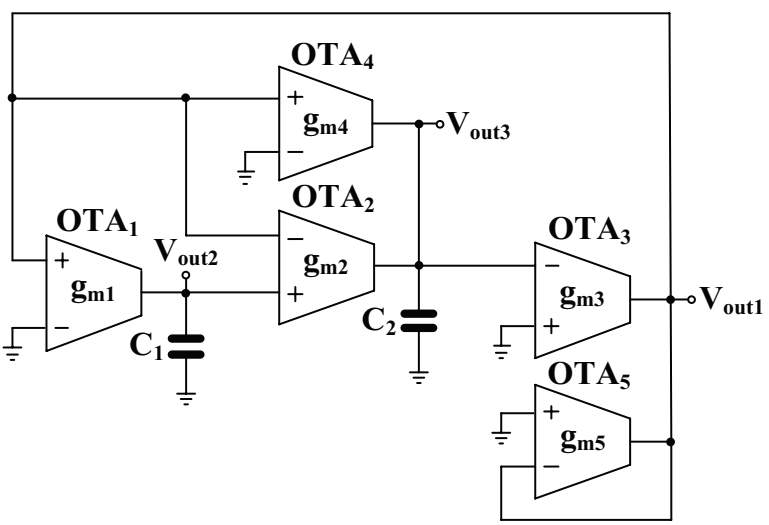

Figure 3: Three-phase quadrature oscillator modified from universal filter.

The universal biquad filter in Fig. 2 has been slightly modified to work as a three-phase quadrature oscillator as shown in Fig. 3. The oscillator can be obtained by interchanging the connections between non-inverting and inverting terminals of OTA 1 and between noninverting and inverting terminals $\mathrm{OTA}_{2}$ in Fig. 2. The inputs $V_{\text {in1 } 1}, V_{\text {in } 3^{\prime}} V_{\text {in } 4}$ are connected to ground while the input $V_{\text {in } 3}$ will connect to the output $V_{\text {out }}$ to creating a positive feedback loop. Thus, the transfer function between $V_{\text {out }}$ and $V_{\text {in } 3}$ of Fig. 2 in case work as oscillator can be expressed as

$$
\frac{V_{\text {out }}}{V_{\text {in } 3}}=\frac{s\left(\frac{C_{1} g_{m 2} g_{m 3}}{g_{m 5}}\right)}{s^{2} C_{1} C_{2}+s\left(\frac{C_{1} g_{m 3} g_{m 4}}{g_{m 5}}\right)+\left(\frac{g_{m 1} g_{m 2} g_{m 3}}{g_{m 5}}\right)}
$$

Setting $\mathrm{V}_{\text {out }} / \mathrm{V}_{\text {in } 3}=1\left(\mathrm{~V}_{\text {out }}\right.$ is connected to $\left.\mathrm{V}_{\text {in }}\right)$, characteristic equation of quadrature oscillator can be expressed by

$$
s^{2}+s \frac{g_{m 3}}{C_{2} g_{m 5}}\left(g_{m 4}-g_{m 2}\right)+\left(\frac{g_{m 1} g_{m 3}}{C_{1} C_{2}} \cdot \frac{g_{m 2}}{g_{m 5}}\right)=0
$$

The condition of oscillator (CO) and frequency of oscillation (FO) can be expressed respectively by

$$
g_{m 4}=g_{m 2}
$$

$\omega_{o}=\sqrt{\frac{g_{m 1} g_{m 3}}{C_{1} C_{2}} \cdot \frac{g_{m 2}}{g_{m 5}}}$

Letting $g_{m 2}=g_{m 5^{\prime}}(10)$ can be simply expressed by

$\omega_{o}=\sqrt{\frac{g_{m 1} g_{m 3}}{C_{1} C_{2}}}$

From (9) and (11), it is evident that the $\mathrm{CO}$ can be controlled electronically by $g_{\mathrm{m} 4}$ and keeping $g_{\mathrm{m} 2}=g_{\mathrm{m} 5}$ and the FO can be controlled electronically and independently by $\mathrm{g}_{\mathrm{m} 1}$ and/or $\mathrm{g}_{\mathrm{m} 3}$ and keeping $\mathrm{C}_{1}=\mathrm{C}_{2}$. Thus, the proposed quadrature oscillator provides electronically and independently control of CO and FO.

It should be noted that the quadrature oscillator in Fig. 3 provides three output terminals $\mathrm{V}_{\text {out } 1} \mathrm{~V}_{\text {out } 2}$ and $\mathrm{V}_{\text {out } 3}$. To express that three output-terminals provide sinusoidal with $90^{\circ}$ phase different, the transfer functions can be expressed by

$\frac{V_{\text {out } 2}}{V_{\text {out } 1}}=\frac{g_{m 1}}{s C_{1}}$

$\frac{V_{\text {out } 3}}{V_{\text {out } 2}}=\frac{g_{m 2}}{s C_{2}}$

Letting $s=j \omega_{o}$, (12) and (13) can be rewritten respectively as $V_{\text {out } 1}=j\left(\omega_{o} C_{1} / g_{m 1}\right) V_{\text {out } 2}$ and $V_{\text {out } 2}=j\left(\omega_{o} C_{2} / g_{m 2}\right) V_{\text {out } 3 \text { which indicates that the }}$ voltages $\mathrm{V}_{\text {out1 }}, \mathrm{V}_{\text {out2 }}, \mathrm{V}_{\text {out3 }}$ are in the quadrature form.

The universal filter in Fig. 2 and quadrature oscillator in Fig. 3 can be blended into single topology. Fig. 4 shows the proposed programmable universal filter and quadrature oscillator. Universal filter and quadrature oscillator can be programmed by analog switches SW and $\mathrm{SW}_{2}$. The commercially available analog switches i.e., MAX14689, MAX4735, TMUX1136, TS3A44159, CD4016B, can be used to implement switches SW $\mathrm{W}_{1}$ and $\mathrm{SW}_{2}$. Assume that analog switch MAX14689 [58] is used in Fig. 4 for selecting a universal filter or a quadrature oscillator.

The status of switch can be controlled by CB (i.e., logic " 0 " or " 1 "). Assume that the present status of $\mathrm{SW}_{1}$ and 


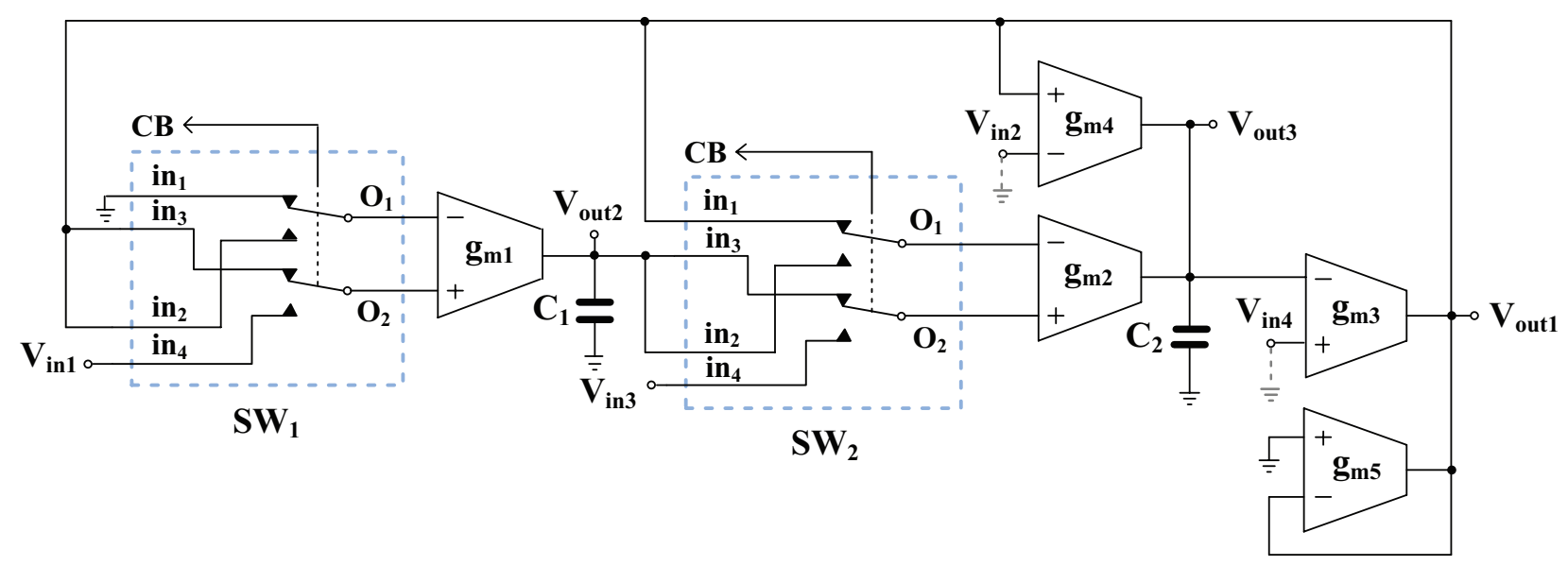

Figure 4: Proposed programmable filter and quadrature oscillator.

$\mathrm{SW}_{2}$ as shown Fig. 4 is $\mathrm{CB}=0$ (i.e., " $\mathrm{O}^{\prime}=0 \mathrm{~V}$ ), the circuit will be worked as a quadrature oscillator by connecting $V_{\text {in } 2}$ and $V_{\text {in } 4}$ to ground. Three-phase outputs can be obtained as $V_{\text {out } 1}, V_{\text {out } 2^{2}}, V_{\text {out3 }}$. It should be noted that the operation of the circuit in this case is similar the quadrature oscillator in Fig. 3.

Continually, if the status of $S W_{1}$ and $S W_{2}$ is $C B=1$ (i.e., $" 1 "=5 \mathrm{~V}$ ), the circuit in Fig. 4 will be operated as a universal filter by applying the input signals to $\mathrm{V}_{\text {in } 1}, \mathrm{~V}_{\text {in2 }}, \mathrm{V}_{\text {in } 3}$ and $V_{\text {in } 4}$ while the output signal is obtained as $V_{\text {out } 1}$. The operation of circuit in this case is similar the universal filter in Fig. 2. Therefore, the proposed circuit can be worked as universal filter and quadrature oscillator by programming technique. There is no topology that operates similar the proposed circuit available in open literature. The condition for obtaining universal filter and quadrature oscillator is concluded in Table 3.

Table 3: Using proposed programmable universal filter and quadrature oscillator

\begin{tabular}{|l|c|c|c|}
\hline Circuit type & $\begin{array}{c}\mathrm{SW}_{1} \text { and } \\
\mathrm{SW}_{2}\end{array}$ & $\begin{array}{c}\text { Input termi- } \\
\text { nal }\end{array}$ & Output node \\
\begin{tabular}{|l|c|c|} 
Quadrature \\
oscillator
\end{tabular} & $\mathrm{CB}=0$ & $\begin{array}{c}\mathrm{V}_{\text {in2 }}=\mathrm{V}_{\text {ind }}=0 \\
\text { (grounded) }\end{array}$ & $\begin{array}{c}\mathrm{V}_{\text {out1 } 1}, \mathrm{~V}_{\text {out2 }} \\
\mathrm{V}_{\text {out3 }}\end{array}$ \\
\hline $\begin{array}{l}\text { Universal } \\
\text { filter }\end{array}$ & $\mathrm{CB}=1$ & $\begin{array}{c}\mathrm{V}_{\text {in1 } 1}, \mathrm{~V}_{\text {in2 }}, \mathrm{V}_{\text {in31 }} \\
\mathrm{V}_{\text {in } 4}\end{array}$ & $\mathrm{~V}_{\text {out1 } 1}=\mathrm{V}_{\text {out }}$ \\
\hline
\end{tabular}

\section{Non-ideal analysis}

Considering non-idealities of OTA, non-ideal transconductance gain $\mathrm{g}_{\mathrm{mni}}$ is given by

$$
g_{m n i}(s)=\frac{g_{m i} \omega_{g i}}{s+\omega_{g i}}
$$

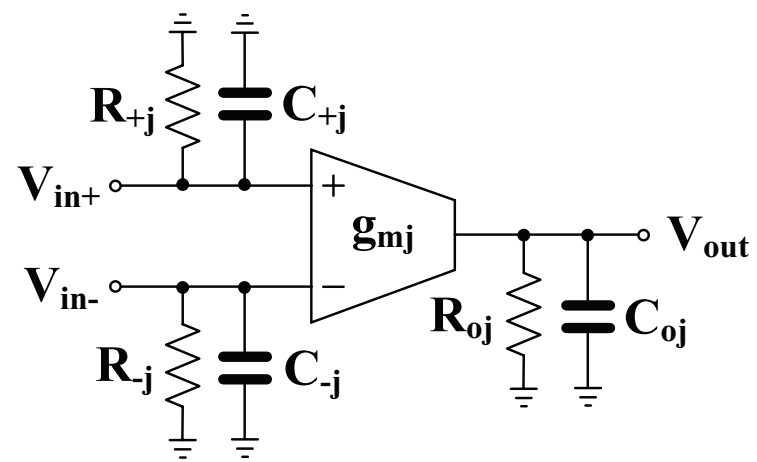

Figure 5: Modeling the non-idealities in the OTA [16].

where $\omega_{\mathrm{gi}}$ and $\mathrm{g}_{\mathrm{mi}}$ denote the first-order pole frequency and the open-loop transconductance gain of OTA $(i=$ $1,2, . ., n)$. In the frequency range of interest of this paper, $g_{m n i}$ can be modified as [17]

$g_{m n i}(s) \cong g_{m i}\left(1-\mu_{i} s\right)$

where $\mu_{i}=1 / \omega_{g i}$.

Consider first-order pole frequency $\omega_{\text {gi }}$ it is a result of the parasitic input and output resistances $\left(R_{\text {in }}\right.$ and $\left.R_{0}\right)$ and the input and output capacitances $\left(C_{i n}\right.$ and $\left.C_{0}\right)$ as shown in Fig. 5. The high-resistance and small-capacitance values will be resulted to high-value of $\omega_{g i}$ and small-value of $\mu_{i}$.

Using (15), denominator of transfer function of universal filter can be written as

$s^{3} C_{1} g_{m 3} g_{m 4}\left(\mu_{3} \mu_{4}-B\right)+s^{2} C_{1} C_{2}(1-C)+s C_{1} g_{m 3} g_{m 4}(1-D)+A$

Were

$A=g_{m 1} g_{m 2} g_{m 3}$ 
$B=\frac{C_{1} C_{2} \mu_{5}+A \mu_{1} \mu_{2} \mu_{3}}{C_{1} g_{m 3} g_{m 4}}$

$C=\frac{C_{1} g_{m 3} g_{m 4} \mu_{3}+C_{1} g_{m 3} g_{m 4} \mu_{4}-A \mu_{1} \mu_{2}-A \mu_{1} \mu_{3}-A \mu_{2} \mu_{3}}{C_{1} C_{2}}$

$D=\frac{A \mu_{1}+A \mu_{2}+A \mu_{3}}{C_{1} g_{m 3} g_{m 4}}$

For the effect of OTA parasitic elements, it can be neglected by satisfying the following condition:

$$
\left.\begin{array}{l}
B \cong \mu_{3} \mu_{4} \\
C<<1 \\
D<1
\end{array}\right\}
$$

The various passive and active sensitivities on the parameters $\omega_{\circ}$ and $Q$ of the universal filter can be expressed as

$$
\begin{aligned}
& S_{g_{m 1}}^{\omega_{o}}=S_{g_{m 2}}^{\omega_{o}}=S_{g_{m 3}}^{\omega_{o}}=-S_{g_{m 5}}^{\omega_{o}}=-S_{C_{1}}^{\omega_{o}}=-S_{C_{2}}^{\omega_{o}}=\frac{1}{2} \\
& S_{g_{m 1}}^{Q}=S_{g_{m 2}}^{Q}=S_{g_{m 5}}^{Q}=S_{C_{2}}^{Q}=-S_{g_{m 3}}^{Q}=-S_{C_{1}}^{Q}=\frac{1}{2} \\
& S_{g_{m 4}}^{Q}=-1
\end{aligned}
$$

Thus, all incremental parametric sensitivities for parameters $\omega_{0}$ and $Q$ are within 1 which has low active and passive sensitivities.

\section{Simulation and experimental results}

\subsection{Simulation results}

The proposed universal filter and quadrature oscillator has been simulated using $0.18 \mu \mathrm{m}$ CMOS technology from TSMC. The CMOS OTA in Fig. 6 [59] was used and the switch was implemented using MOS transistors as shown in Fig 7. If $C B=$ logic " 0 ", switch will be turned on and it will be turned-off if $C B=$ logic "1". Fig. 8 shows analog switch that used to program universal filter and quadrature oscillator and its operation was similar Table 2 . The power supply of $\pm 1.2 \mathrm{~V}$ was used. The aspect ratios of NMOS and PMOS were given respectively as $5 \mu \mathrm{m} / 1 \mu \mathrm{m}$ and $10 \mu \mathrm{m} / 1 \mu \mathrm{m}$ [59]. The logic " 0 " of $0 \mathrm{~V}$ and logic " 1 " of $1.2 \mathrm{~V}$ were given. The performances of OTA and MOS switch were summarized in Table 4.

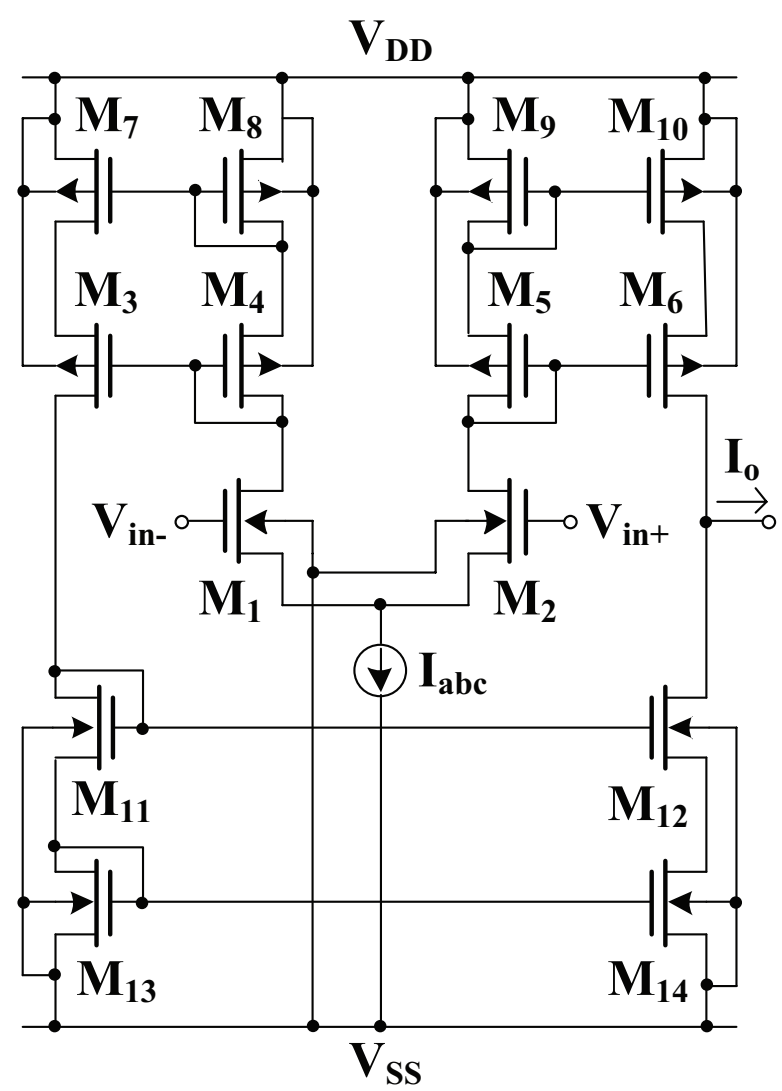

Figure 6: CMOS implementation for OTA [59].

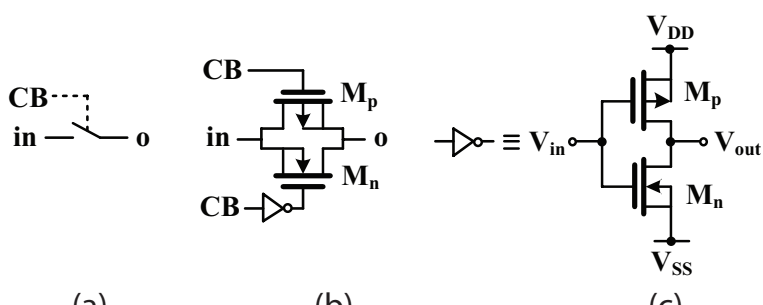

(a)

(b)

(c)

Figure 7: Switch implementation: (a) symbol, (b) MOS switch, (c) CMOS inverter.

Table 4: Simulated specifications of CMOS OTA and MOS switch.

\begin{tabular}{|l|c|} 
Parameter & Value \\
\hline Technology & $0.18 \mu \mathrm{m}$ \\
\hline Power supply & $\pm 1.2 \mathrm{~V}$ \\
\hline OTA & 12 to $220 \mu \mathrm{A} / \mathrm{V}$ \\
\hline $\mathrm{g}_{\mathrm{m}}\left(\mathrm{I}_{\mathrm{abc}}=1-50 \mu \mathrm{A}\right)$ & $23 \mathrm{MHz}$ \\
\hline $\begin{array}{l}\text { Bandwidth }(-3 \mathrm{~dB}) @ \mathrm{I}_{\mathrm{abc}}=1 \mu \mathrm{A} \\
\text { @ } \mathrm{I}_{\mathrm{abc}}=50 \mu \mathrm{A}\end{array}$ & $300 \mathrm{MHz}$ \\
\hline $\begin{array}{l}\text { Parasitic parameters @ } \mathrm{I}_{\mathrm{abc}}=50 \mu \mathrm{A} \\
\mathrm{R}_{\mathrm{o}} / / \mathrm{C}_{\mathrm{o}}\end{array}$ & $38.6 \mathrm{M} \Omega / / 18 \mathrm{fF}$ \\
\hline Power consumption @ $\mathrm{I}_{\mathrm{abc}}=50 \mu \mathrm{A}$ & $240 \mu \mathrm{W}$ \\
\hline MOS switch & $320 \Omega$ \\
\hline $\mathrm{R}_{\mathrm{on}}$ & $380 \mathrm{M} \Omega$ \\
\hline $\mathrm{R}_{\text {off }}$ & \\
\hline
\end{tabular}


(a)

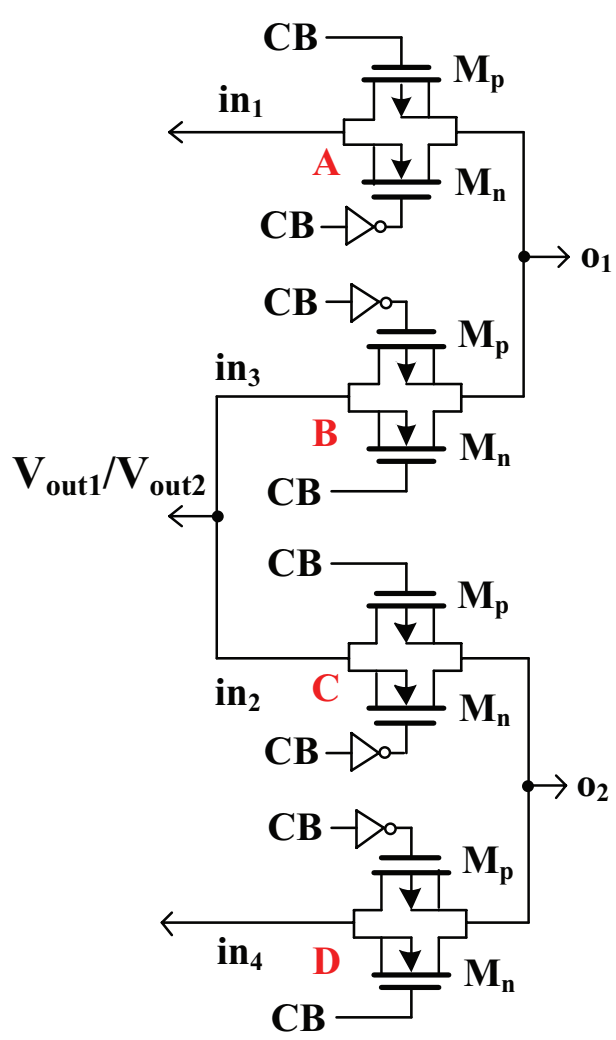

(b)

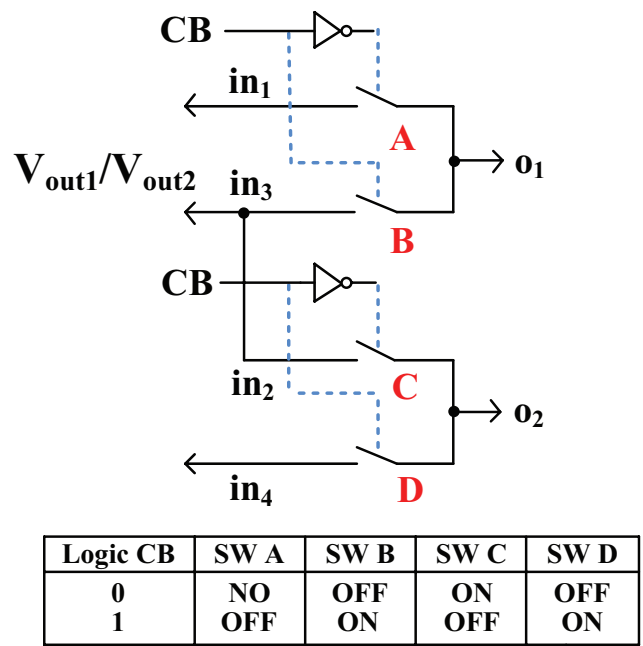

Figure 8: Analog switch implementation: (a) circuit, (b) symbol.

First case, the circuit has been operated as a universal filter by setting $C B=" 1$ " $(1.2 \mathrm{~V})$. The capacitors $C_{1}=C_{2}$ $=22 \mathrm{pF}$ and the bias currents $\mathrm{I}_{\mathrm{abc} 1}=\mathrm{I}_{\mathrm{abc} 2}=\mathrm{I}_{\mathrm{abc} 3}=\mathrm{I}_{\mathrm{abc} 4}=\mathrm{I}_{\mathrm{abc} 5}$ $=20 \mu \mathrm{A}\left(\mathrm{g}_{\mathrm{m}}=139.86 \mu \mathrm{S}\right)$ were designed. This setting has been designed to obtain the LP, BP, HP, BS, and AP filter responses with $f_{\mathrm{o}} \cong 1 \mathrm{MHz}$ and $\mathrm{Q}=1$.

Fig. 9 shows the simulated frequency responses of the $L P, H P, B P$, and $B S$ filters of the proposed filter. At natural frequency, the notch depth of attenuation in case of BS filter was about $-25 \mathrm{~dB}$ which should be less than -30 $\mathrm{dB}$ for an acceptable level. It causes from the parasitic parameters of OTAs which deeper the notch of attenuation can be obtained when the filter was operated as lower natural frequency. Fig. 10 shows the simulated frequency responses of the gain and phase characteristics of the AP filter. It was evident from Figs. 9 and 10 that the proposed circuit provides five standard filtering responses without inverting-type input signal.

Fig. 11 shows the simulated frequency response of BP filter when the biasing currents $\mathrm{I}_{\mathrm{abc}}\left(\mathrm{l}_{\mathrm{abc}}=\mathrm{I}_{\mathrm{abc}}=\mathrm{l}_{\mathrm{abc}}\right)$ were respectively adjusted for the values of $5,10,20$ and 50 $\mu \mathrm{A}$. This result was confirmed that the natural frequency can be electronically controlled. Fig. 12 shows the simulated frequency response of BP filter when the biasing current $\mathrm{I}_{\text {abc } 4}$ was respectively varied for the values of $2,5,20$, and $50 \mu \mathrm{A}$. This result was confirmed that the proposed circuit provides orthogonal and electronic controls for parameters $\omega_{\mathrm{o}}$ and $\mathrm{Q}$.

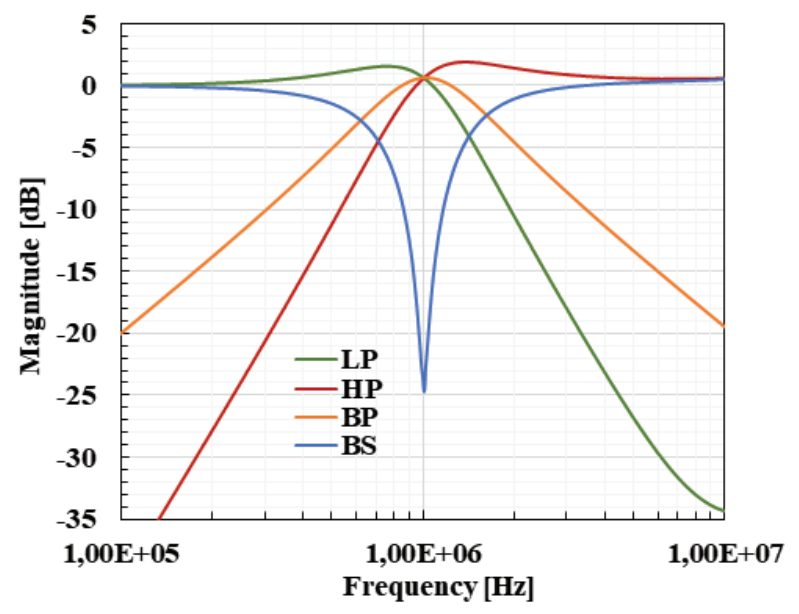

Figure 9: Simulated frequency responses of $L P, H P, B P$, and BS filters.

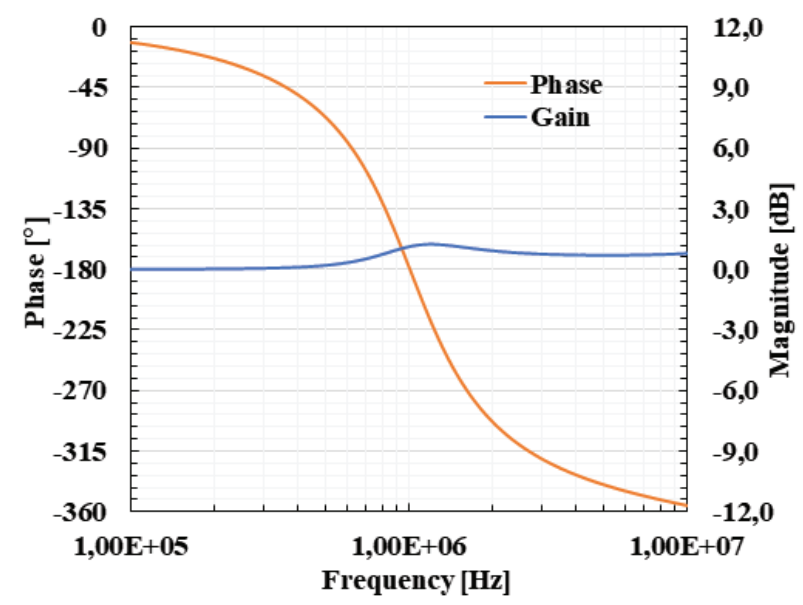

Figure 10: Simulated gain and phase responses of AP filters. 


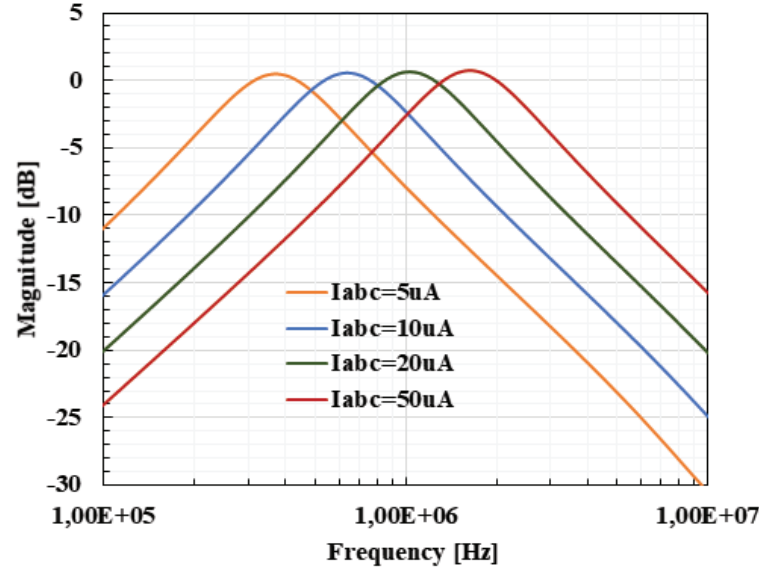

Figure 11: Simulated frequency responses of BP with different $\omega_{0}$.

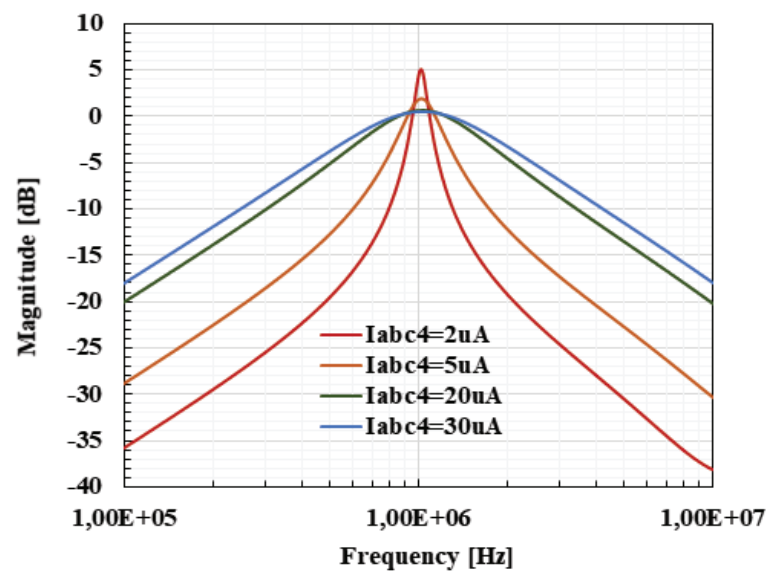

Figure 12: Simulated frequency responses of BP with different $\mathrm{Q}$.

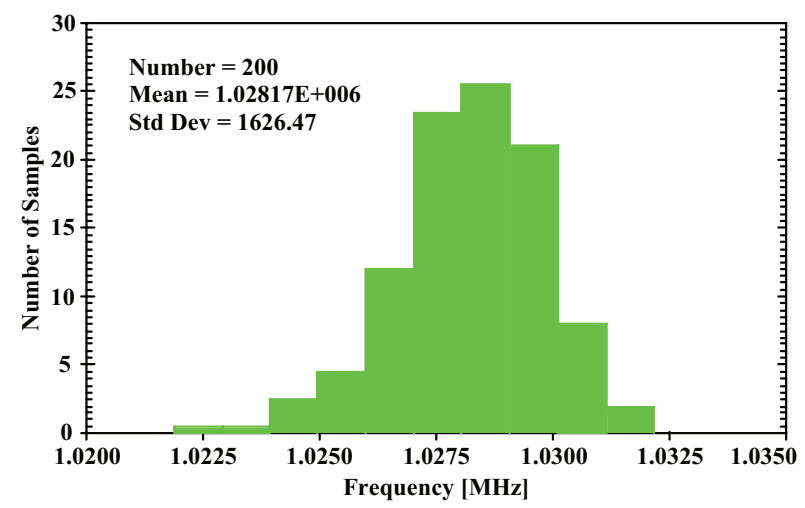

Figure 13: Simulated histogram of Monte-Carlo analysis for BP filter.

The Monte Carlo analysis of the frequency response with $5 \%$ variations of the transistor threshold voltage was performed. Fig. 13 shows the results of Monte Carlo analysis using 200 runs. From the derived histogram of $f_{\mathrm{o}^{\prime}}$ it can be expressed that the standard deviation $(\sigma)$ was $1.626 \mathrm{kHz}$, the mean was $1.028 \mathrm{MHz}$ and there-

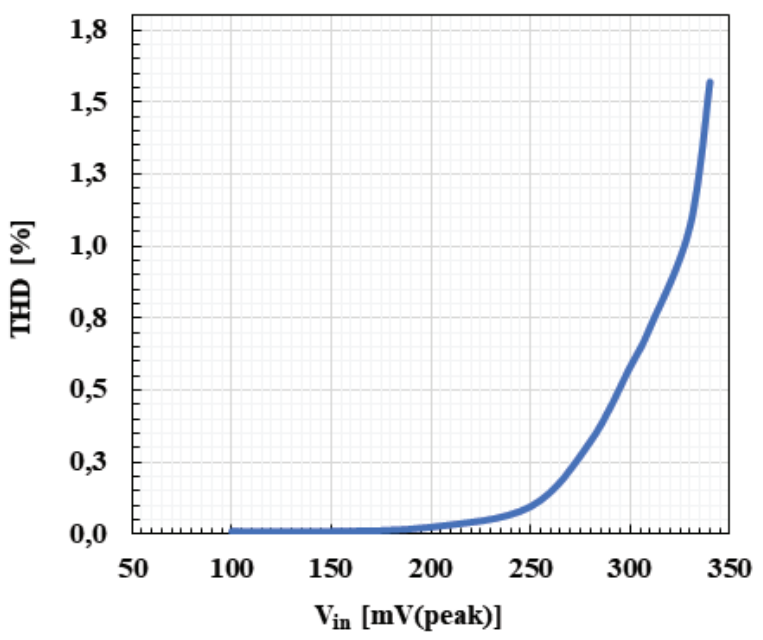

Figure 14: Simulated THD of LP filter

for the minimal and maximal of $f_{\mathrm{o}}$ were $1.021 \mathrm{MHz}$ and $1.032 \mathrm{MHz}$, respectively. This result can be used to confirm the reliability of circuit functionality in case transistor mismatch on the CMOS OTA-based filter.

The dependence of the output harmonic distortion of low-pass filter on input voltage amplitude was shown in Fig. 14. It expresses that the THD was below $1 \%$ for the input signal of $320 \mathrm{mV}$ (peak).

Second case, the circuit has been operated as a quadrature oscillator by setting $\mathrm{CB}=$ " 0 " $(\mathrm{OV})$. The biasing

(a)

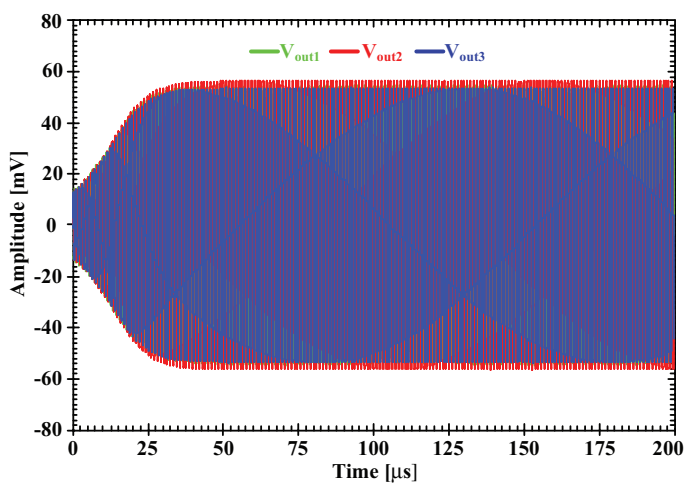

(b)

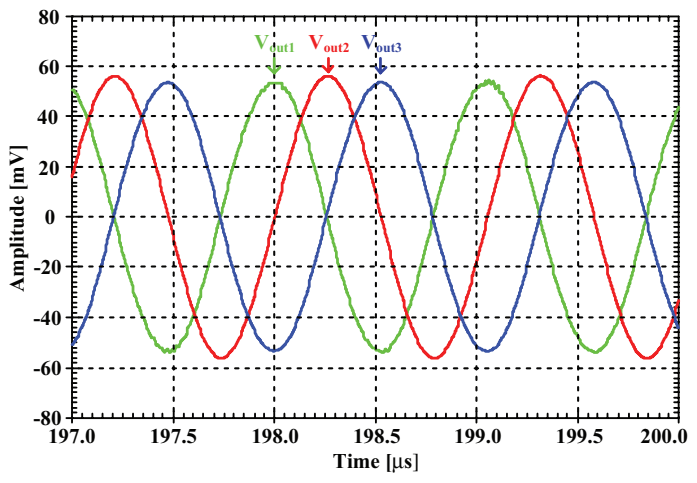

Figure 15: (a) simulated of the quadrature outputs $\mathrm{V}_{\text {out } 1}, \mathrm{~V}_{\text {out2 }}, \mathrm{V}_{\text {out3' }}$ (b) steady state. 
current $\mathrm{I}_{\mathrm{abc} 4}(\cong 18.6 \mu \mathrm{A})$ was used to adjust $\mathrm{g}_{\mathrm{m} 4}$ for controlling the condition of oscillator. Fig. 15 shows the quadrature sinusoidal output waveforms of oscillator. This result shows a frequency of $0.95 \mathrm{MHz}$ whereas theoretical value was $1.01 \mathrm{MHz}$. Fig. 16 shows the plot of the frequency of oscillation for varying the value of bias currents $I_{a b c}\left(I_{a b c}=I_{a b c 1}=I_{a b c 3}\right)$ from 5 to $50 \mu \mathrm{A}$. Theoretical value was used to confirm simulation results.

Fig. 17 shows output signal levels of $\mathrm{V}_{\text {out1 } 1}, \mathrm{~V}_{\text {out2 }}$ and $\mathrm{V}_{\text {out3 }}$ versus the frequency of oscillation. Total harmonic distortion (THD) and phase error were respectively shown in Figs. 18 and 19.

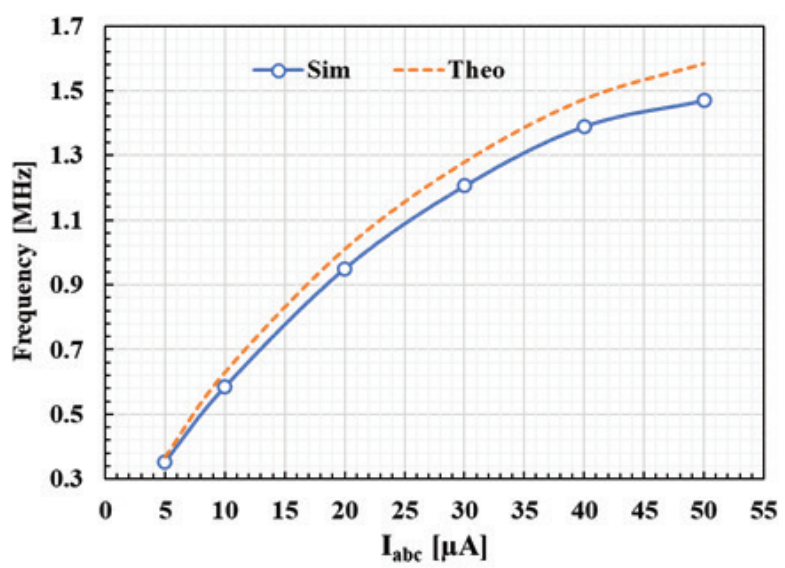

Figure 16: Simulated frequency of oscillation against biasing currents.

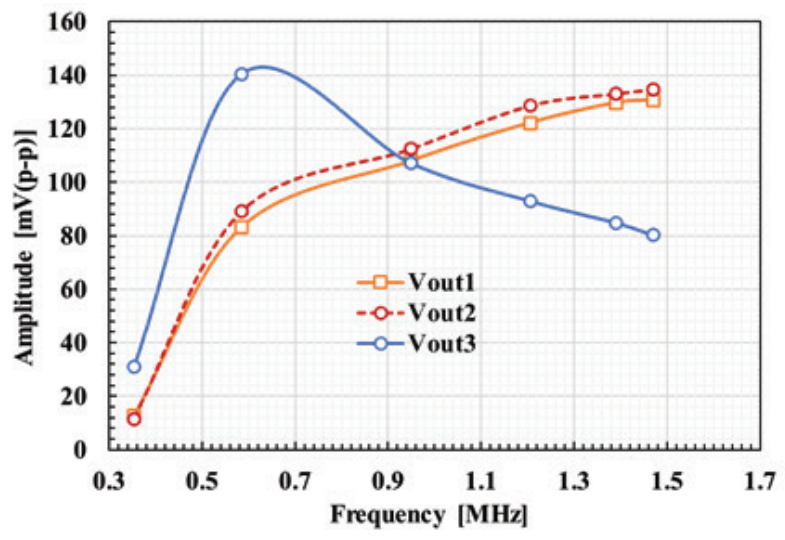

Figure 17: Simulated frequency of oscillation against voltage output amplitude.

\subsection{Experimental results}

To check the workability of proposed circuit, simulation and experiment tests have been performed simultaneously. The circuit was evaluated by SPICE simulator and experiment test using commercial OTA LM13600 [60]. The switches $\mathrm{SW}_{1}$ and $\mathrm{SW}_{2}$ were implemented using 4-channel analog switch CD4016B [61] and it was also available in PSPICE library. Fig. 20 shows the design of

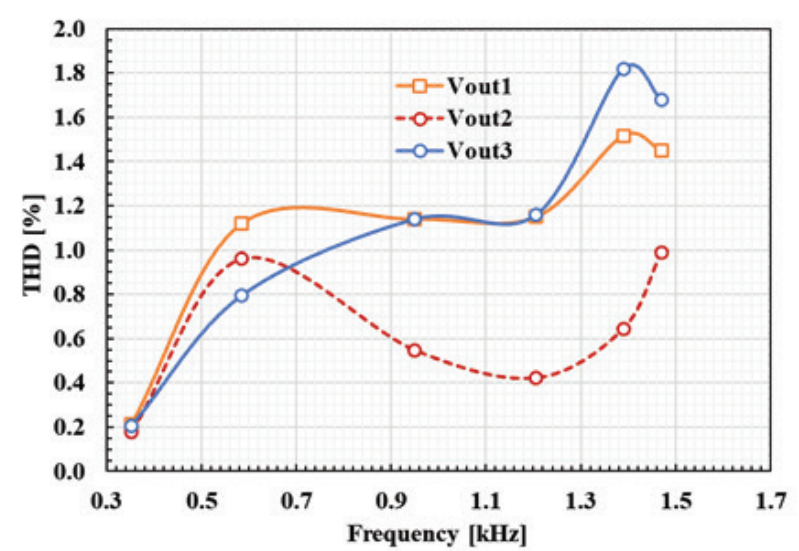

Figure 18: Simulated THD as a function of frequency of oscillation.

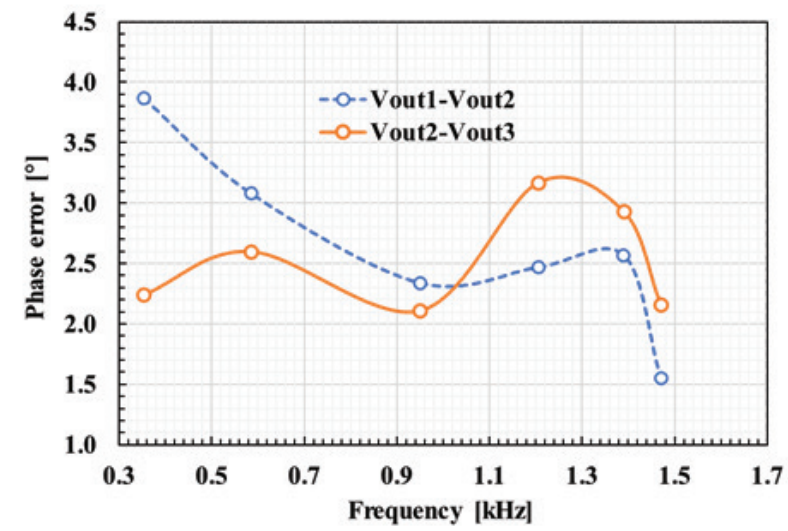

Figure 19: Simulated phase error as a function of frequency of oscillation.

$\mathrm{SW}_{1}$ and $\mathrm{SW}_{2}$ using 4-channel analog switch CD4016B that can be used in Fig. 4, namely $C B=$ logic " 0 " for quadrature oscillator and $C B=$ logic " 1 " for universal filter. The convention inverter 74LS04 have been used. The supply voltages were selected as $\mathrm{V}_{\mathrm{DD}}=-\mathrm{V}_{\mathrm{SS}}=5 \mathrm{~V}$ and capacitances $C_{1}$ and $C_{2}$ were given as $2.2 \mathrm{nF}$. The sinusoidal input signal and the measured output waveforms were taken using Agilent Technologies DSO-X 2002A oscilloscope.

First case, the circuit will be operated as universal filter. The transconductances $g_{\mathrm{m} 1}=g_{\mathrm{m} 2}=g_{\mathrm{m} 3}=g_{\mathrm{m} 4}=g_{\mathrm{m} 5}=$ $1.512 \mathrm{mS}\left(\mathrm{g}_{\mathrm{m}}=\mathrm{I}_{\mathrm{ABC}} / 2 \mathrm{~V}_{\mathrm{T}} \mathrm{I}_{\mathrm{ABC}}=78.02 \mu \mathrm{A}\right)$ were designed to obtain the filter with natural frequency of $f_{\mathrm{o}}=109.38$ $\mathrm{kHz}$ and quality factor of $\mathrm{Q}=1$. The bias current $\mathrm{I}_{\mathrm{ABC}}$ of $78.02 \mu \mathrm{A}$ can be obtained by using resistance $\left(\mathrm{R}_{\mathrm{ABC}}\right)$ of $47 \mathrm{k} \Omega$. To obtain $C B=\operatorname{logic}$ " 0 " and $C B=\operatorname{logic}$ " 1 ", the voltage was set respectively as $0 \mathrm{~V}$ and $5 \mathrm{~V}$.

Fig. 21 shows magnitude responses of LP, HP, BP, and BS responses with natural frequency of $f_{o}=109 \mathrm{kHz}$. Fig. 22 shows magnitude and phase responses of AP filter. Fig. 23 shows magnitude responses of BP filters when the values of $g_{m}\left(g_{m}=g_{m 1}=g_{m 3}\right)$ were varied with the 
(a)

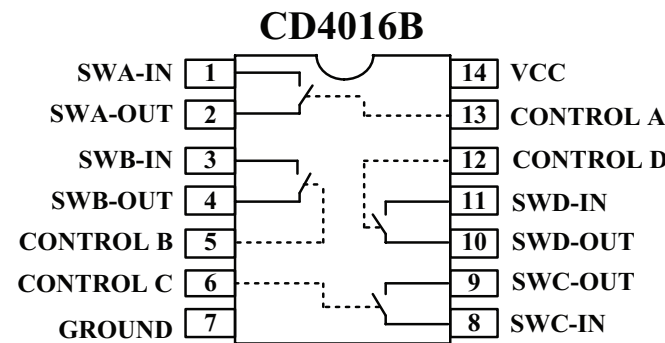

(b)

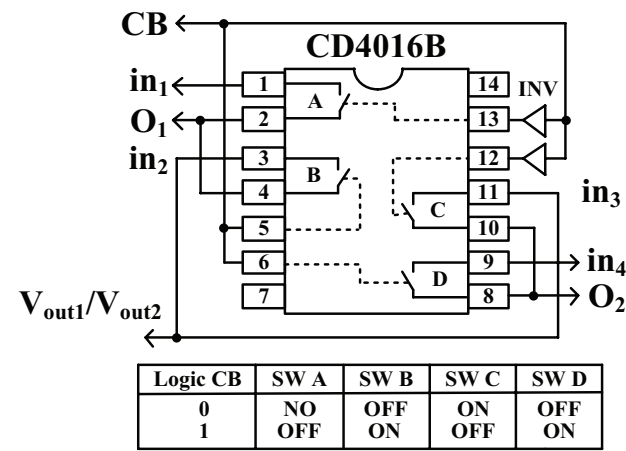

Figure 20: 4-channel analog switch CD4016B: (a) CD4016B pinout, (b) Implementation for $\mathrm{SW}_{1}$ and $\mathrm{SW}_{2}$.

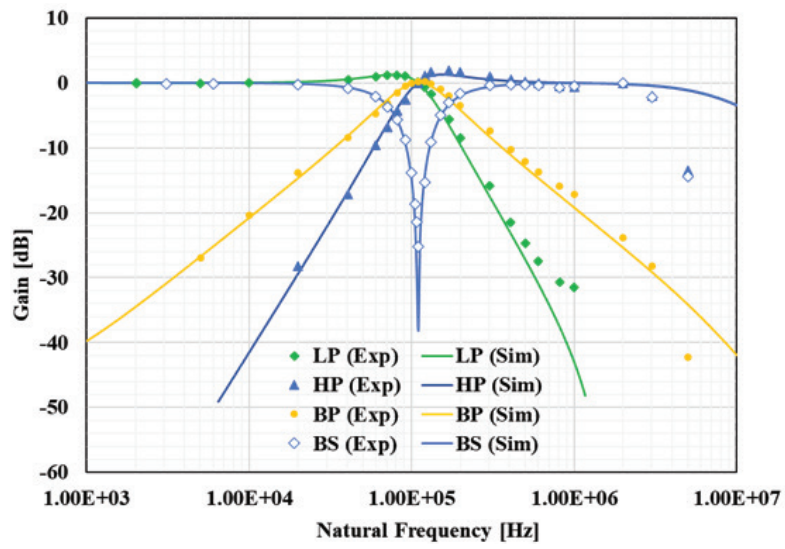

Figure 21: Magnitude responses of $L P, B P, H P$, and $B S$ filter.

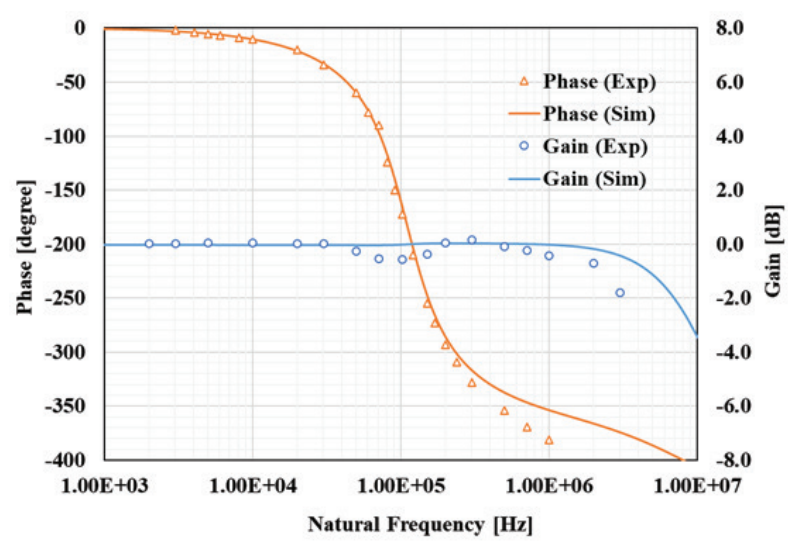

Figure 22: Magnitude and phase responses of AP filter.

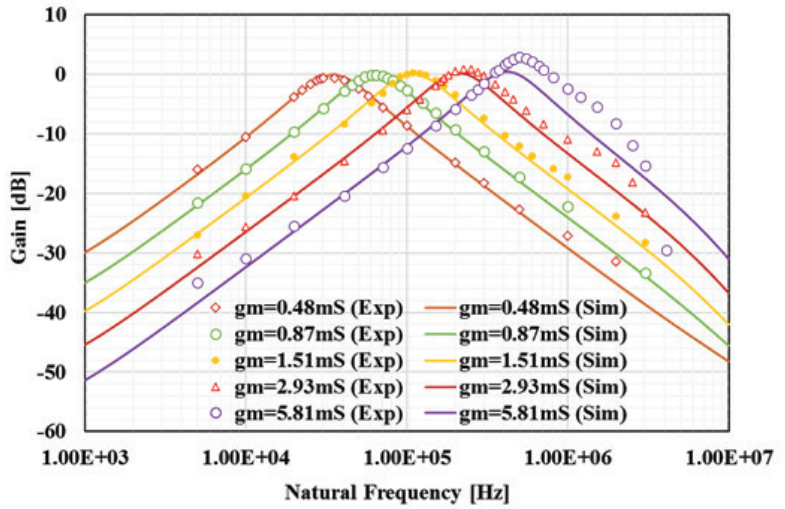

Figure 23: Magnitude responses of BP filter with different parameter $\omega_{\circ}$.

values of $0.481 \mathrm{mS}\left(\mathrm{I}_{A B C}=24.84 \mu \mathrm{A}, \mathrm{R}_{A B C}=150 \mathrm{k} \Omega\right), 0.873$ $\mathrm{mS}\left(\mathrm{I}_{A B C}=45.06 \mu \mathrm{A}, \mathrm{R}_{A B C}=82 \mathrm{k} \Omega\right), 1.512 \mathrm{mS}, 2.934 \mathrm{mS}$ $\left(\mathrm{I}_{\mathrm{ABC}}=151.4 \mu \mathrm{A}, \mathrm{R}_{\mathrm{ABC}}=24 \mathrm{k} \Omega\right)$ and $5.81 \mathrm{mS}\left(\mathrm{I}_{\mathrm{ABC}}=299.8\right.$ $\mu A, R_{A B C}=12 \mathrm{k} \Omega$ ). In Fig. 23, the natural frequency $f_{\mathrm{o}}$ was varied from $38.9 \mathrm{kHz}, 63.2 \mathrm{kHz}, 109 \mathrm{kHz}, 212.3 \mathrm{kHz}$ and $419.7 \mathrm{kHz}$ when $\mathrm{g}_{\mathrm{m}}$ was varied respectively from 0.481 $\mathrm{mS}, 0.873 \mathrm{mS}, 1.512 \mathrm{mS}, 2.934 \mathrm{mS}$ and $5.81 \mathrm{mS}$. Fig. 24 shows magnitude responses of BP filters when the values of $g_{m}\left(g_{m 2}=g_{m 5}=g_{m}\right)$ were varied with different values of $0.873 \mathrm{mS}, 1.512 \mathrm{mS}, 2.934 \mathrm{mS}, 5.81 \mathrm{mS}, 8.45$ $\mathrm{mS}\left(\mathrm{I}_{\mathrm{ABC}}=436.3 \mu \mathrm{A}, \mathrm{R}_{\mathrm{ABC}}=8.2 \mathrm{k} \Omega\right)$ to express different parameter $\mathrm{Q}$, while $\mathrm{g}_{\mathrm{m} 4}$ was fixed as $1.512 \mathrm{mS}$.

The LP filter has been used to test the distortion of the universal filter by setting the natural frequency of 109 $\mathrm{kHz}$ and applying the input frequency of $1 \mathrm{kHz}$. Fig. 25 shows total harmonic distortion (THD) parameter of the LP filter when the amplitude was varied. It expresses that the amplitude of $115 \mathrm{mV}_{\text {(peak) }}$ THD was $1 \%$.

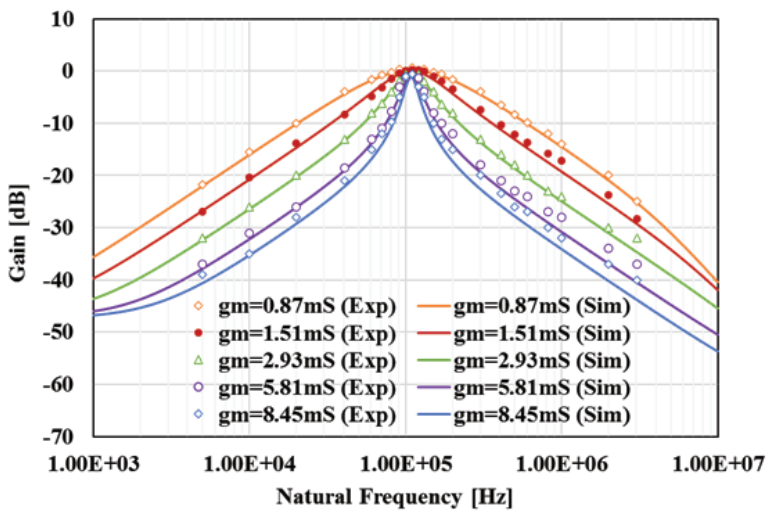

Figure 24: Magnitude responses of BP filter with different parameter $\mathrm{Q}$.

Temperature stability of the proposed filter on parameter $\omega_{0}$ was simulated by varying temperature from $-10^{\circ}$ to $80^{\circ}$ which was shown in Fig. 26. When the temperature was varied from -10 to 80 , the corresponding $f_{\text {o }}$ 


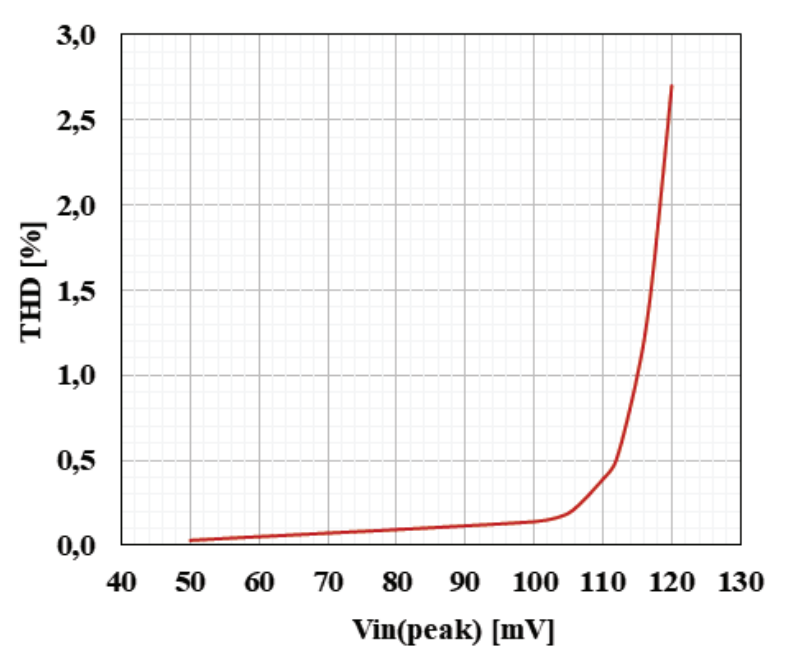

Figure 25: THD variations of the LP filter versus amplitudes of the input voltage at $1 \mathrm{kHz}$.

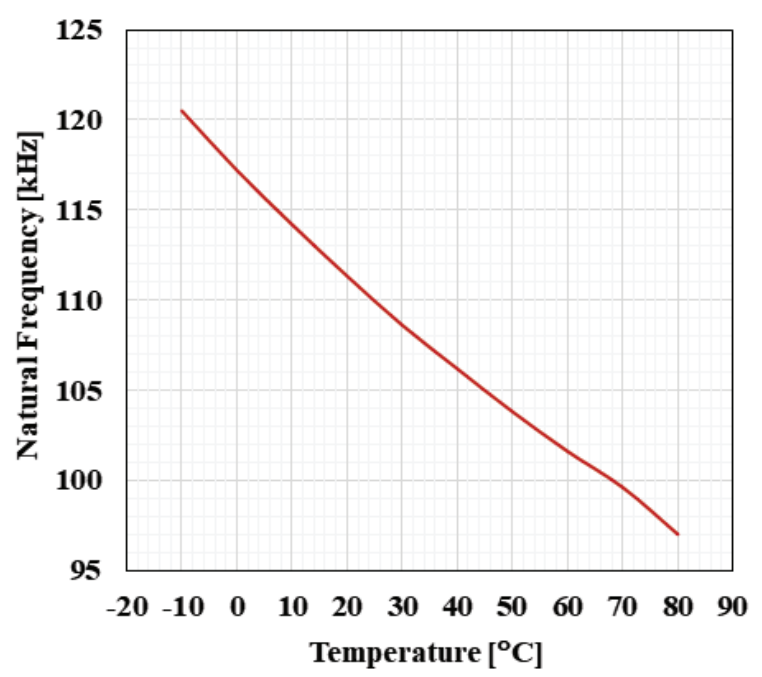

Figure 26: Natural frequency variations of the BP filter versus temperatures.

was changed from $120.5 \mathrm{kHz}$ to $97 \mathrm{kHz}$. Temperature stability has been investigated because BJT OTA was used in this case, better temperature stability will be obtained if CMOS OTA was used.

The proposed quadrature oscillator was also evaluated by SPICE simulation and experiment test using commercial OTA LM13600. The parameter was set similar the case of universal filter. Namely, the supply voltages were $V_{D D}=-V_{S S}=5 \mathrm{~V}$ and the capacitances $C_{1}$ and $\mathrm{C}_{2}$ were $2.2 \mathrm{nF}$. The measured output waveforms were taken using Tektronix MSO 4034 mixed signal oscilloscope (4-channel oscilloscope).

Fig. 27 shows measured output wave forms of $\mathrm{V}_{\text {out1 } 1}, \mathrm{~V}_{\text {out2 }}$ and $\mathrm{V}_{\text {out3 }}$ when the circuit was designed as $\mathrm{g}_{\mathrm{m} 1}=\mathrm{g}_{\mathrm{m} 2}=$ $\mathrm{g}_{\mathrm{m} 3}=\mathrm{g}_{\mathrm{m} 5}=1.512 \mathrm{mS}\left(\mathrm{R}_{\mathrm{ABC}}=47 \mathrm{k} \Omega\right)$ and $\mathrm{g}_{\mathrm{m} 4} \cong 1.48 \mathrm{mS}$ $\left(\mathrm{I}_{\mathrm{ABC}}=76.4 \mu \mathrm{A}: \mathrm{R}_{\mathrm{ABC}}=48 \mathrm{k} \Omega\right)$ was used for controlling the CO. The circuit generates the frequency of $96.7 \mathrm{kHz}$ while theoretical value was $109.38 \mathrm{kHz}$, and the amplitudes were nearly equaled. The quadrature output form in Fig. 28 was verified through the XY mode. The quadrature relationships between $V_{\text {out1 }}$ and $V_{\text {out2 }}$ and between $V_{\text {out2 }}$ and $V_{\text {out3 }}$ were shown in Fig. 28, (a) and (b), respectively.

The experimental result of the FO by changing the value of transconductances $g_{m}\left(g_{m}=g_{m 1}=g_{m 3}\right)$ was shown in Fig. 29. From this figure, when the transconductances $g_{m}$ was changed as $0.481 \mathrm{mS}\left(R_{A B C}=150 \mathrm{k} \Omega\right), 0.873 \mathrm{mS}$ $\left(\mathrm{R}_{\mathrm{ABC}}=82 \mathrm{k} \Omega\right), 1.512 \mathrm{mS}\left(\mathrm{R}_{\mathrm{ABC}}=47 \mathrm{k} \Omega\right), 2.934 \mathrm{mS}\left(\mathrm{R}_{\mathrm{ABC}}=24\right.$ $\mathrm{k} \Omega), 5.81 \mathrm{mS}\left(\mathrm{R}_{A B C}=12 \mathrm{k} \Omega\right), 8.45 \mathrm{mS}\left(\mathrm{R}_{A B C}=8.2 \mathrm{k} \Omega\right)$, the FO was changed respectively as $32.7 \mathrm{kHz}, 58.5 \mathrm{kHz}, 96.7$ $\mathrm{kHz}, 200 \mathrm{kHz}, 395 \mathrm{kHz}$, and $580 \mathrm{kHz}$. The theoretical value has been used to compare the experimental result.

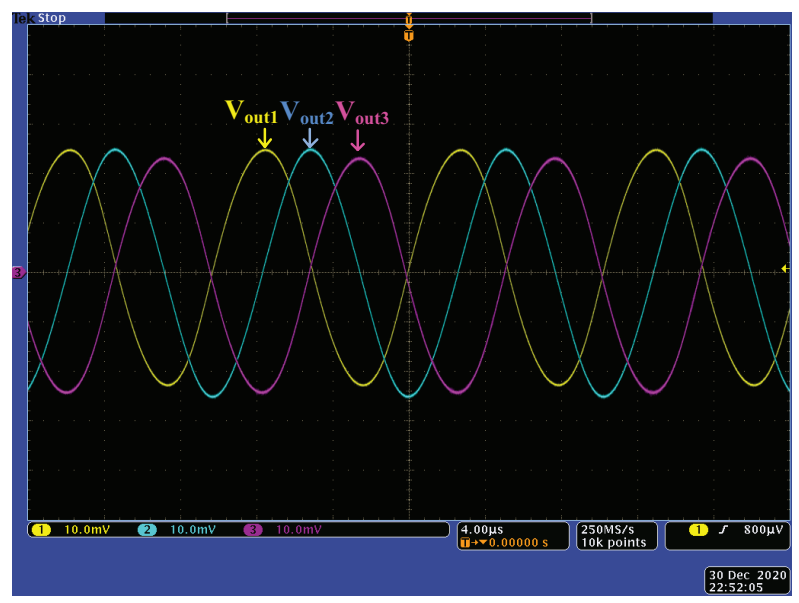

Figure 27: The experimental of quadrature outputs $\mathrm{V}_{\text {out1 }}, \mathrm{V}_{\text {out2 }}, \mathrm{V}_{\text {out3. }}$

The plot for amplitude versus FO was shown in Fig. 30. Compared with Fig. 17, it should be noted that when $g_{m}$ $\left(g_{m}=g_{m 1}=g_{m 3}\right)$ was varied far from $1.512 \mathrm{mS}$ (lower and higher from $1.512 \mathrm{mS}$ ), the amplitude of $V_{\text {out1 }}, V_{\text {out2 }}$ and $\mathrm{V}_{\text {out3 }}$ will be changed. The amplitudes of $\mathrm{V}_{\text {out1 } 1}$ and $\mathrm{V}_{\text {out2 }}$ will increase while the amplitude of $\mathrm{V}_{\text {out3 }}$ will decrease when the FO was increased. If the constant amplitude of output signals was required, it can be obtained using the amplitude-automatic gain control (AGC) circuit [57]. The THD of output signals $V_{\text {out } 1}, V_{\text {out2 }}$ and $V_{\text {out3 }}$ was plotted and shown in Fig. 31. It should be noted that large amplitude of output signal will be suffered from high THD. Fig. 32 shows the phase error that outputs between $\mathrm{V}_{\text {out } 1}$ and $\mathrm{V}_{\text {out2 }}$, between $\mathrm{V}_{\text {out2 }}$ and $\mathrm{V}_{\text {out3 }}$ deviated from $90^{\circ}$ phase different. 
(a)

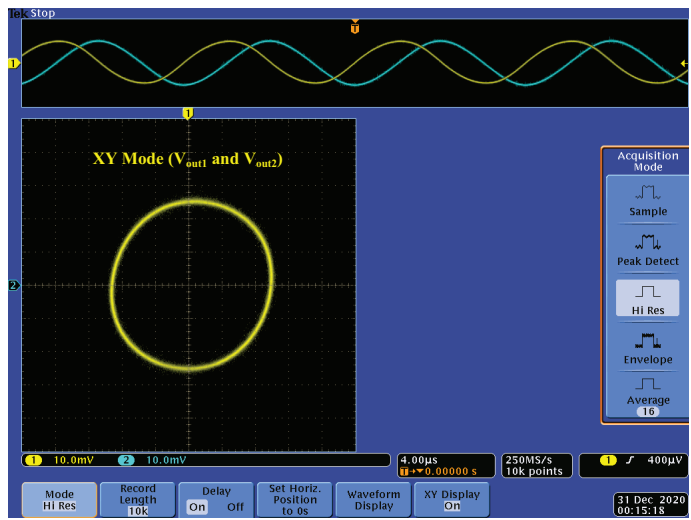

(b)

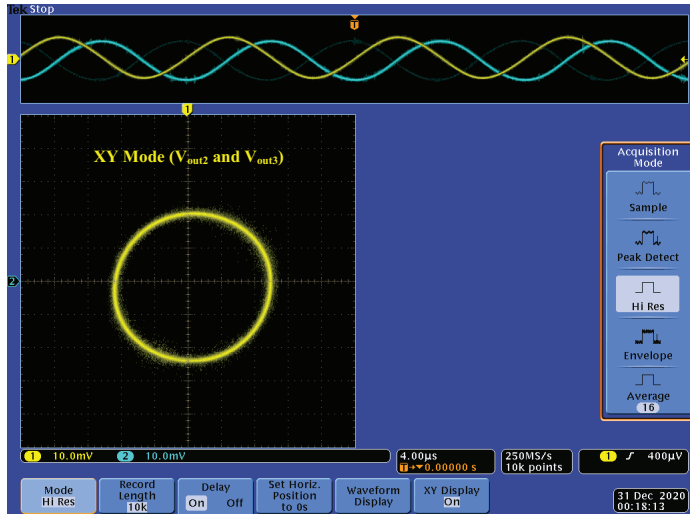

Figure 28: Lissajous pattern: (a) $\mathrm{V}_{\text {out } 1}$ and $\mathrm{V}_{\text {out2 }}$ outputs, (b) $V_{\text {out } 2}$ and $V_{\text {out3 }}$ outputs.

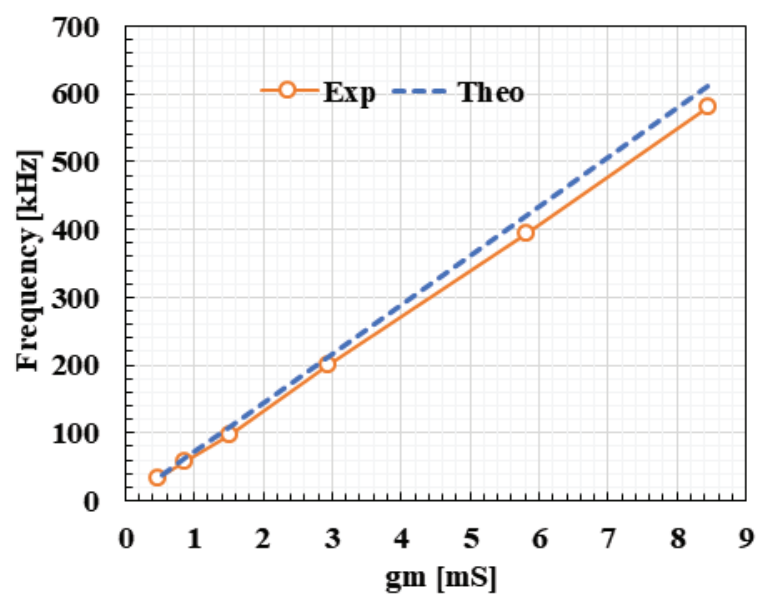

Figure 29: The frequency of oscillation against transconductances $g_{m}$.

\section{Conclusions}

In this paper, a new programmable voltage-mode universal filter and quadrature oscillator using five single output OTAs and two grounded capacitors is presented. The circuit uses analog switch to program either a universal filter or a quadrature oscillator. When the circuit performs function as filter, it is a four-input single-

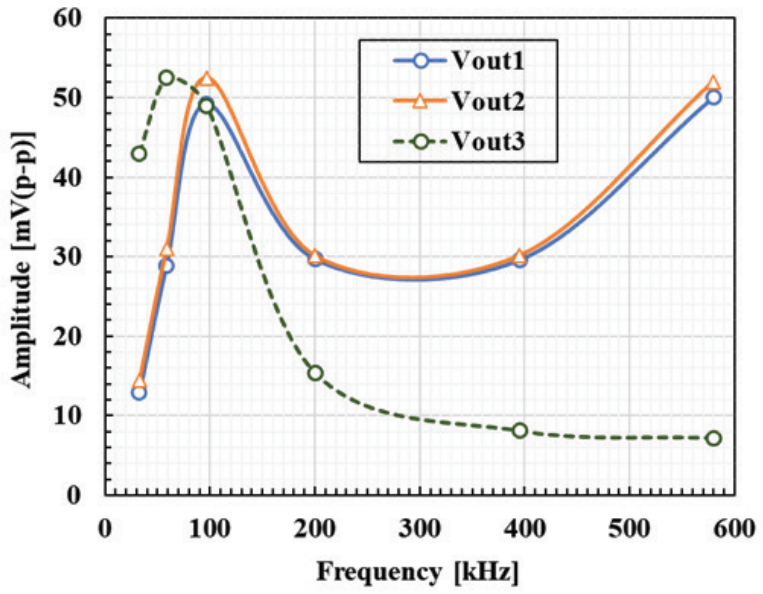

Figure 30: Output amplitude against the frequency of oscillation.

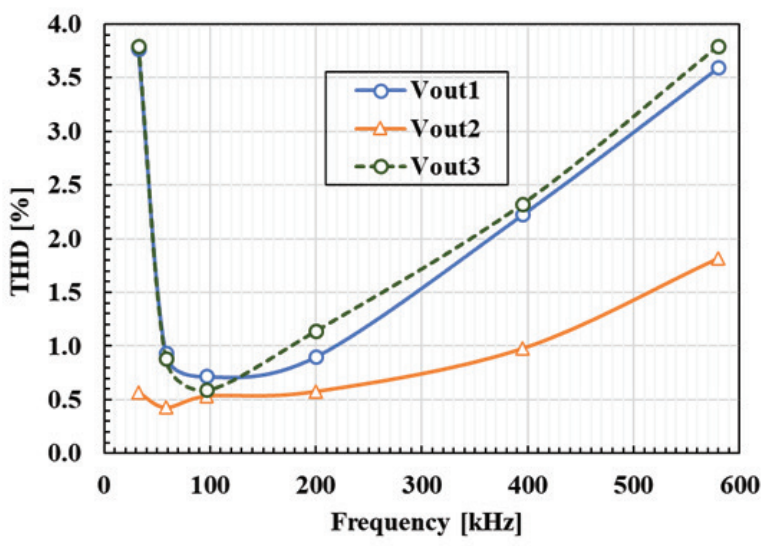

Figure 31: THD as a function of frequency of oscillation.

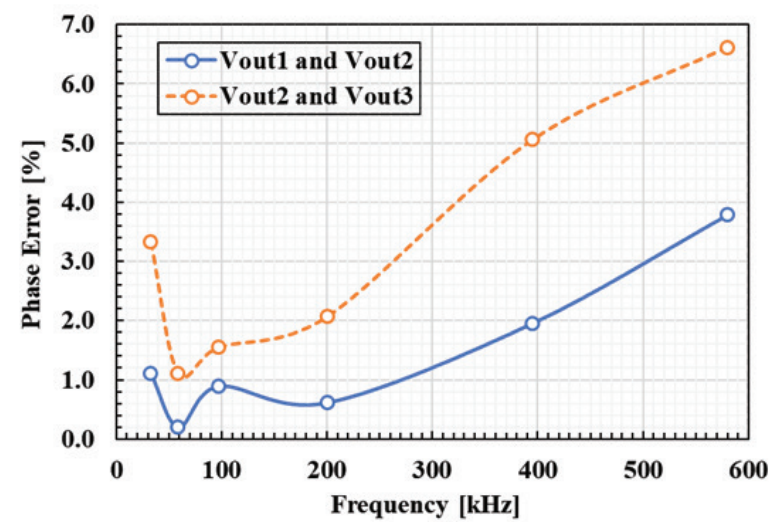

Figure 32: Phase error as a function of the frequency of oscillation.

output universal filter that can be realized LP, BP, HP, BS, and $A P$ voltage responses by applying the input terminals appropriately at high input impedance. The natural frequency and the quality factor can be controlled electronically and independently by adjusting the bias currents of OTAs. Neither component-matching con- 
ditions nor inverting-type input signals is required for obtaining five standard filtering functions. When the circuit works as quadrature oscillator, it is a three-phase quadrature oscillator that the condition and frequency of oscillation of oscillator can be independently and electronically controlled. The proposed structure is realized based on single output OTAs which is easily implemented in both as commercially available ICs as OTAs and CMOS as IC forms. The functionality of the proposed circuit is confirmed by SPICE simulation and experiment test.

\section{Acknowledgments}

This work was supported by King Mongkut's Institute of Technology Ladkrabang under grant KREF026201.

\section{References}

1. R. L. Geiger, E. Sanchez-Sinencio, "Active filter design using operational transconductance amplifiers: a tutorial,"IEEE Circuits and Devices Magazine, vol. 1, pp. 20-32, 1985. https://doi.org/10.1109/MCD.1985.6311946

2. E. Sanchez-Sinencio, J. Ramirez-Angulo, B. Linares-Barranco, A. Rodriguez-Vazquez, “Operational transconductance amplifier-based nonlinear function syntheses," IEEE Journal of Solid-State Circuits, vol. 24, pp. 1579-1586, 1989. https://doi.org/10.1109/4.44993

3. C. K. Alexander, M. N. O. Sadiku, Fundamentals of Electric Circuits, New York, McGraw-Hill, 2004. ISBN 978-0-07-338057-5

4. R. Schaumann, M. S. Ghausi, K. R. Laker, Design of Analog Filter: Passive, Active RC, and Switched Capacitor, New Jersey, Prentice Hall, 1990. ISBN-10 0132002884

5. A. Ranjan, S. Perumalla, R. Kumar, V. John, S. Yumnam, "Second order universal filter using four-terminal floating nullor (FTFN)," Journal of Circuits, Systems and Computers, vol. 28, 1950091, 2019. https://doi.org/10.1142/S0218126619500919

6. W. Jaikla, F. Khateb, M. Kumngern, T. Kulej, R. K. Ranjan, P. Suwanjan, "0.5 V fully differential universal filter based on multiple input OTAs," IEEE Access, vol. 8, pp. 187832-187839, 2020. https://doi.org/10.1109/ACCESS.2020.3030239

7. D. Singh, S. K. Paul, "Realization of current mode universal shadow filter," AEU-International Journal of Electronics and Communications, vol. 117, 153088, 2020.

https://doi.org/10.1016/j.aeue.2020.153088
8. H. Alpaslan, E. Yuce, "DVCC+ based multifunction and universal filters with the high input impedance features," Analog Integrated Circuits and Signal Processing, vol. 103, pp. 325-335, 2020. https://doi.org/10.1007/s10470-020-01643-8

9. M. T. Abuelma'atti, A. Bentrcia, "A novel mixedmode OTA-C universal filter," International Journal of Electronics, vol. 92, pp. 375-383, 2005. https://doi.org/10.1080/08827510412331295009

10. M. Kumngern, P. Suwanjan, K. Dejhan, “Electronically tunable voltage-mode universal filter with single-input five-output using simple OTAs," International Journal of Electronics, vol. 100, pp. 11181133, 2013. https://doi.org/10.1080/00207217.2012.743070

11. H.-P. Chen, Y.-Z. Liao, W.-T. Lee, "Tunable mixedmode OTA-C universal filter," Analog Integrated Circuits and Signal Processing, vol. 58, pp. 135141, 2009.

https://doi.org/10.1007/s10470-008-9228-z

12. C.-N. Lee, "Multiple-mode OTA-C universal biquad filter," Circuits, Systems, and Signal Processing, vol. 29, pp. 263-274, 2010.

https://doi.org/10.1007/s00034-009-9145-0

13. M. Kumngern, B. Knobnob, K. Dejhan, "Electronically tunable high-input impedance voltagemode universal biquadratic filter based on simple CMOS OTAs," International Journal of Electronics and Communications, vol. 64, pp. 934-939, 2010. https://doi.org/10.1016/j.aeue.2009.07.015

14. M. Kumngern, "Electronically tunable capacitorgrounded voltage-mode universal filter with three-input one-output using single-ended OTAs," in Proceedings of 2012 IEEE Symposium on Industrial Electronics \& Applications (ISIEA), Indonesia, 2012, pp. 104-107.

https://doi.org/10.1109/ISIEA.2012.6496608

15. N. Wattikornsirikul, M. Kumngern, "Three-input one-output voltage-mode universal filter using simple OTAs," in Proceedings of 2014 12th International Conference on ICT and Knowledge Engineering (ICT and Knowledge Engineering), Thailand, 2014, pp. 28-31. https://doi.org/10.1109/ICTKE.2014.7001530

16. C. Psychalinos, C. Kasimis, F. Khateb, "Multipleinput single-output universal biquad filter using single output operational transconductance amplifiers," International Journal of Electronics and Communications, vol. 93, pp. 360-367, 2018. https://doi.org/10.1016/j.aeue.2018.06.037

17. M. Kumngern, P. Suksaibul, F. Khateb, “Four-input one-output voltage-mode universal filter using simple OTAs," Journal of Circuits, Systems, and Computers, vol. 28, pp. 1950078 (20 pages) 2019. https://doi.org/10.1142/S0218126619500786 
18. S.-F. Wang, H.-Pin Chen, Y. Ku, C.-M. Yang, "A voltage-mode universal filter using five single-ended OTAs with two grounded capacitors and a quadrature oscillator using the voltage-mode universal filter," Optik-International Journal for Light and Electron Optics, vol. 192, 162950, 2019.

https://doi.org/10.1016/j.jileo.2019.162950

19. M. Parvizi, "Design of a new low power MISO multi-mode universal biquad OTA-C filter," International Journal of Electronics, vol. 106, pp. 440-454, 2019.

https://doi.org/10.1080/00207217.2018.1540064

20. D. R. Bhaskar, A. Raj, P. Kumar, "Mixed-mode universal biquad filter using OTAs," Journal of Circuits, Systems, and Computers, vol. 29, 2050162 (22 pages), 2020.

https://doi.org/10.1142/S0218126620501625

21. A. Raj, D. R. Bhaskar, P. Kumar, "Multiple-input single-output universal biquad filter using single output OTAs," 2018 2nd IEEE International Conference on Power Electronics, Intelligent Control and Energy Systems (ICPEICES), Delhi, India, 22-24 October 2018, pp. 1237-1240.

https://doi.org/10.1109/ICPEICES.2018.8897308

22. A. Raj, P. Kumar, D. R. Bhaskar, "Multiple-input single-output universal biquad filters using reduced number of OTAs," 2019 International Symposium on Advanced Electrical and Communication Technologies (ISAECT), Rome, Italy, 27-29 November 2019, pp. 1-4.

https://doi.org/10.1109/ISAECT47714.2019.9069693.

23. T. Tsukutani, M. Higashimura, N. Takahashi, Y. Sumi, Y. Fukai, "Versatile voltage-mode active-only biquad with lossless and lossy integrator loop," International Journal of Electronics, vol. 88, pp. 1093-1101, 2001,

https://doi.org/10.1080/00207210110071279

24. T. Tsukutani, Y. Sumi, Y. Kinucasa, M. Higashimura, Y. Fukai, "Versatile active-only biquad circuits with loss-less and lossy integrator," International Journal of Electronics, vol. 91, pp. 525-536, 2004, https://doi.org/10.1080/00207210412331299851

25. S.-F. Wang, H.-P. Chen, Y. Ku, C.-M. Yang, "Independently tunable voltage-mode OTA-C biquadratic filter with five inputs and three outputs and its fully-uncoupled quadrature sinusoidal oscillator application," AEU-International Journal of Electronics and Communications, vol. 110, 152822, 2019, https://doi.org/10.1016/j.aeue.2019.152822

26. S.-F. Wang, H.-P. Chen, Y. Ku, Y.-C. Lin, "Versatile tunable voltage-mode biquadratic filter and its application in quadrature oscillator," Sensors, vol. 19, 2349, 2019,

https://doi.org/10.3390/s19102349
27. S.-F. Wang, H.-P. Chen, Y.-T. Ku, C.-M. Yang, "A voltage-mode universal filter using five single-ended OTAs with two grounded capacitors and a quadrature oscillator using the voltage-mode universal filter," Optik-International Journal for Light and Electron Optics, vol. 192, 162950, 2019. https://doi.org/10.1016/j.ijleo.2019.162950

28. S.-F. Wang, H.-P. Chen, Y. Ku, C.-L. Lee, "Versatile voltage-mode biquadratic filter and quadrature oscillator using four OTAs and two grounded capacitors," Electronics, vol. 9, 1493, 2020. https://doi.org/10.3390/electronics9091493

29. S. Haykin, M. Moher, An introduction to analog and digital communications, John Wiley \& Sons, New York, 2007. ISBN: 978-0-470-46087-0

30. W. Jaikla, S. Adhan, P. Suwanjan, M. Kumngern, "Current/voltage-controlled quadrature sinusoidal oscillators for phase sensitive detection using commercially available IC," Sensors, vol. 20, 1319, 2020. https://doi.org/10.3390/s20051319

31. R. Sotner, J. Jerabek, L. Langhammer, J. Polak, N. Herencsar, R. Prokop, J. Petrzela, W. Jaikla, “Comparison of two solutions of quadrature oscillators with linear control of frequency of oscillation employing modern commercially available devices," Circuits, Systems, and Signal Processing, vol. 34, p. 3449-3469, 2015. https://doi.org/10.1007/s00034-015-0015-7

32. W. Tangsrirat, "Dual-mode sinusoidal quadrature oscillator with single CCCTA and grounded capacitors," Journal of Microelectronics, Electronic Components and Materials, vol. 46, 130-135, 2016. http://ojs.midem-drustvo.si/index.php/ InfMIDEM/article/view/245

33. S. B. Salem, A. B. Saied, D. S. Masmoudi, "High-performance current-controlled quadrature oscillator using an optimized CCII," Journal of Microelectronics, Electronic Components and Materials vol. 46, pp. 91-99, 2016. http://www.midem-drustvo. si/Journal\%20papers/MIDEM_46(2016)2p91.pdf

34. K. Banerjee, D. Singh, S. K. Paul, "Single VDTA based resistorless quadrature oscillator," Analog Integrated Circuits and Signal Processing, vol. 100, pp. 495-500, 2019. https://doi.org/10.1007/s10470-019-01480-4

35. W. Jaikla, S. Adhan, P. Suwanjan, M. Kumngern, "Current/voltage-controlled quadrature sinusoidal oscillators for phase sensitive detection using commercially available IC," Sensors, vol. 20, 1319, 2020. https://doi.org/10.3390/s20051319

36. S. Gupta, T. S. Arora, "Design and experimentation of VDTA based oscillators using commercially available integrated circuits," Analog Integrated Circuits and Signal Processing, vol. 106, pp. 713728, 2021. https://doi.org/10.1007/s10470-020-01784-w 
37. B. Linares-Barranco, A. Rodriguez-Vbquez, E. Sanchez-Sinencio, J. L. Huertas, "Generation, design and tuning of OTA-C high frequency sinusoidal oscillators," IEE Proceedings-Circuits, Devices and Systems, vol. 139, pp. 557-568, 1992, https://doi.org/10.1049/ip-g-2.1992.0086

38. S. Summart, C. Thongsopa, W. Jaikla, "OTA based current mode sinusoidal quadrature oscillator with non-interactive control," Przeglad Elektrotechniczny, vol. 88, pp. 14-17, 2012, http://pe.org. $\mathrm{pl} /$ articles/2012/7a/3.pdf

39. T. Thosdeekoraphat, C. Thongsopa, S. Summart, C. Seatiaw, "Second order current-mode quadrature oscillators using OTAs," Przeglad Elektrotechniczny, vol. 92, pp. 165-160, 2016. http://pe.org.pl/ articles/2016/2/43.pdf

40. W. Tangsrirat, T. Pukkalanun, W. Surakampontorn, "CDBA-based universal biquad filter and quadrature oscillator," Active and Passive Electronic Components, vol. 2008, Article ID 247171 (6 pages), 2008.

https://doi.org/10.1155/2008/247171

41. W. Tangsrirat, "Novel minimum-component universal filter and quadrature oscillator with electronic tuning property based on CCCDBAs," Indian Journal of Pure and Applied Physics, vol. 47, pp. 815-822, 2009. http://hdl.handle. net/123456789/6200

42. S. Maheshwari, J. Mohan, D. S. Chauhan, "High input impedance voltage-mode universal filter and quadrature oscillator," Journal of Circuits, Systems and Computers, vol. 19, pp. 1597-1607, 2010. https://doi.org/10.1142/S0218126610006943

43. J. Jin, C. Wang, "Current-mode universal filter and quadrature oscillator using CDTAs," Turkish Journal of Electrical Engineering and Computer Sciences, vol. 22, pp. 276-286, 2014. https://doi.org/10.3906/elk-1207-62

44. J. Jin, "Resistorless active SIMO universal filter and four-phase quadrature oscillator," Arabian Journal for Science and Engineering, vol. 39, pp. 38873894, 2014. https://doi.org/10.1007/s13369-014-0985-y

45. S. Tuntrakoon, M. Kumngern, R. Sotner, N. Herencsar, P. Suwanjan, W. Jaikla, “High input impedance voltage-mode universal filter and its modification as quadrature oscillator using VDDDAs," Indian Journal of Pure and Applied Physics, vol. 55, pp. 324-332, 2017. http://op.niscair.res.in/index.php/ IJPAP/article/viewFile/14214/1241

46. M. Gupta, P. Dogra, T. S. Arora, "Novel current mode universal filter and dual-mode quadrature oscillator using VDCC and all grounded passive elements," Australian Journal of Electrical and Electronics Engineering, vol. 16, pp. 220-236, 2019. https://doi.org/10.1080/1448837X.2019.1648134
47. T. S. Arora, B. Rohil, S. Gupta, "Fully integrable/ cascadable CM universal filter and CM quadrature oscillator using VDCC and only grounded passive elements," Journal of Circuits, Systems and Computers, vol. 28, 1950181 (36 pages), 2019. https://doi.org/10.1142/S0218126619501810

48. F. Yucel, E. Yuce, "Supplementary CCII based second-order universal filter and quadrature oscillators," AEU-International Journal of Electronics and Communications, vol. 118, 153138, 2020. https://doi.org/10.1016/j.aeue.2020.153138

49. W. Tangsrirat, T. Pukkalanun, O. Channumsin, "Single VDGA-based dual-mode multifunction biquadratic filter and quadrature sinusoidal oscillator," Journal of Microelectronics, Electronic Components and Materials, vol. 50, pp.125-136, 2020. https://doi.org/10.33180/InfMIDEM2020.205

50. M. Siripruchyanun, W. Jaikla, "Cascadable currentmode biquad filter and quadrature oscillator using DO-CCClls and OTA," Circuits, Systems, and Signal Processing, vol. 28, pp. 99-110, 2009. https://doi.org/10.1007/s00034-008-9072-5

51. W. Jaikla, M. Siripruchyanun, A. Lahiri, "Resistorless dual-mode quadrature sinusoidal oscillator using a single active building block," Microelectronics Journal, vol. 42, pp. 135-140, 2011, https://doi.org/10.1016/j.mejo.2010.08.017

52. M. Gupta, T. S. Arora, "Realization of current mode universal filter and a dual-mode single resistancecontrolled quadrature oscillator employing VDCC and only grounded passive elements," Advances in Electrical and Electronic Engineering, vol. 15, pp. 833-845, 2017. https://doi.org/10.15598/aeee.v15i5.2397

53. M. Gupta, T. S. Arora, "Various applications of analog signal processing employing voltage differencing current conveyor and only grounded passive elements: a re-convertible approach," SN Applied Sciences, vol. 2, 2020. https://doi.org/10.1007/s42452-020-03379-6

54. H.-P. Chen, Y.-S. Hwang, Y.-T. Ku, S.-F. Wang, C.-H. $\mathrm{Wu}$, "Voltage-mode universal biquadratic filter and quadrature oscillator using CFAs" IEICE Electronics Express, vol. 13, pp. 1-11, 2016. https://doi.org/10.1587/elex.13.20160510

55. Y. A. Li, "Electronically tunable current-mode biquadratic filter and four-phase quadrature oscillator," Microelectronics Journal, vol. 45, pp. 330335, 2014, https://doi.org/10.1016/j.mejo.2013.12.005

56. M. Kumngern, E. Wareechol, P. Phasukkit, "Quadrature oscillator and universal filter based on translinear current conveyors," AEU-International Journal of Electronics and Communications, vol. 94, pp. 69-78, 2018, https://doi.org/10.1016/j.aeue.2018.06.044 
57. M. Kumngern, F. Khateb, "Current-mode universal filter and quadrature oscillator using current controlled current follower transconductance amplifiers," Analog Integrated Circuits and Signal Processing, vol. 100, pp. 235-248, 2019, https://doi.org/10.1007/s10470-018-1345-8

58. https://www.maximintegrated.com/en/products/analog/analog-switches-multiplexers/ MAX14689.html

59. S.-H. Tu, C.-M. Chang, J. N. Ross, M. N. S. Swamy, "Analytical synthesis of current-mode high-order single-ended-input OTA and equal-capacitor elliptic filter structures with the minimum number of components," IEEE Transactions on Circuits and Systems-I, vol. 54, pp. 2195-2210, 2007, https://doi.org/10.1109/TCSI.2007.905644

60. Texas Instruments, LM13700: Dual Operational Transconductance Amplifier with Linearizing Diodes and Buffers. URL http://www.ti.com/product/LM13700; 2015.

61. Texas Instruments, CD4016B: 4-channel analog switch, URL https://www.ti.com/product/ CD4016B

62. R. Sotner, J. Jerabek, L. Langhammer, J. Polak, N. Herencsar, P. Prokop, J. Petrzela, W. Jaikla, "Comparison of two solutions of quadrature oscillators with linear control of frequency of oscillation employing modern commercially available devices," Circuits, Systems, and Signal Processing, vol. 34, pp. 3449-3469, 2015. https://doi.org/10.1007/s00034-015-0015-7

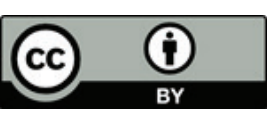

Copyright (c) 2021 by the Authors. This is an open access article distributed under the Creative Commons Attribution (CC BY) License (https://creativecommons.org/licenses/by/4.0/), which permits unrestricted use, distribution, and reproduction in any medium, provided the original work is properly cited.

Arrived: 22. 06. 2021

Accepted: 02. 11. 2021 